\title{
Evaluation of the compounds commonly known as superoxide dismutase and catalase mimics in cellular models
}

\author{
Amandine Vincent, ${ }^{[a]}$ Marion Thauvin, ${ }^{[b],[c]}$ Elodie Quévrain, ${ }^{[a]}$ Emilie Mathieu, ${ }^{[a]}$ Sarah \\ Layani, ${ }^{[d]}$ Philippe Seksik, ${ }^{[d]}$ Ines Batinic-Haberle, ${ }^{[e]}$ Sophie Vriz, ${ }^{[b],[f]}$ Clotilde Policar $^{[a]^{*}}$ and \\ Nicolas Delsuc ${ }^{[a]^{*}}$
}

[a] Laboratoire des biomolécules, LBM, Département de chimie, Ecole Normale Supérieure, PSL University, Sorbonne Université, CNRS, 75005 Paris, France

E-mail: nicolas.delsuc@ens.psl.eu

[b] Centre Interdisciplinaire de Recherche en Biologie (CIRB), CNRS UMR7241/INSERM U1050/Collège de France, 75231 Paris, Cedex 05, France

[c] Sorbonne Université, 4 place Jussieu, 75005, Paris, France

[d] Centre de Recherche Saint Antoine, INSERM, UMRS 938, Metabolism-Inflammation Department, 184 rue du Faubourg Saint-Antoine, 75012 Paris France

[e] Department of Radiation Oncology, Duke University School of Medicine, Durham, NC 27710

[f] Université de Paris, Faculty of Science - 75006 Paris, France

\begin{abstract}
Oxidative stress that results from an imbalance between the concentrations of reactive species (RS) and antioxidant defenses is associated with many pathologies. Superoxide dismutase (SOD), catalase (CAT), and glutathione peroxidase are among the key enzymes that maintain the low nanomolar physiological concentrations of superoxide and hydrogen peroxide. The increase in the levels of these species and their progeny could have deleterious effects. In this context, chemists have developed SOD and CAT mimics to supplement them when cells are overwhelmed with oxidative stress. However, the beneficial activity of such molecules in cells depends not only on their intrinsic catalytic activities but also on their stability in biological context, their cell penetration and their cellular localization. We have employed cellular assays to characterize several compounds that possess SOD and CAT activities and have been frequently used in cellular and animal models. We used cellular assays that address SOD and CAT activities of the compounds. Finally, we determined the effect of compounds on the suppression of the inflammation in HT29-MD2 cells challenged by lipopolysaccharide. When the assay requires penetration inside cells, the SOD mimics $\mathrm{Mn}(\mathrm{III})$ mesotetrakis(N-(2'-nbutoxyethyl)pyridinium-2-yl)porphyrin $\quad\left(\mathrm{MnTnBuOE}-2-\mathrm{PyP}^{5+}\right)$ and $\mathrm{Mn}(\mathrm{II})$ dichloro[(4aR,13aR,17aR,21aR)-1,2,3,4,4a,5, 6, $\quad 6,12,13,13 \mathrm{a}, 14,15,16,17,17 \mathrm{a}, 18,19,20,21,21 \mathrm{a}-$ eicosahydro-11,7-nitrilo-7Hdibenzo[b,h][1,4,7,10] tetra--azacycloheptadecine$\kappa N 5, \kappa N 13, \kappa N 18, \kappa N 21, \kappa N 22$ ] (Imisopasem manganese, M40403, CG4419) were found efficacious at $10 \mu \mathrm{M}$, while $\mathrm{Mn}$ (II) chloro N-(phenolato)-N,N'-bis[2-(N-methyl-imidazolyl)methyl]-ethane-1,2diamine (Mn1) requires an incubation at $100 \mu \mathrm{M}$. This study thus demonstrates that MnTnBuOE-2$\mathrm{PyP}^{5+}, \mathrm{M} 40403$ and Mn1 were efficacious in suppressing inflammatory response in HT29-MD2 cells and such action appears to be related to their ability to enter the cells and modulate reactive oxygen species (ROS) levels.
\end{abstract}




\section{Introduction}

Oxidative stress is associated with many physiological pathologies such as diabetes, inflammatory bowel diseases, cancers, and neurodegenerative diseases [1]. It results from an imbalance between the concentration of reactive species (RS) responsible for deleterious damages, and antioxidant defenses [2]. Among naturally occurring antioxidants, the metalloenzymes superoxide dismutases (SOD), catalase (CAT) and glutathione peroxidases (GPxs) play crucial roles in redox homeostasis. SODs catalyze the dismutation of the superoxide anion $\mathrm{O}_{2}{ }^{-}$into $\mathrm{H}_{2} \mathrm{O}_{2}$ and $\mathrm{O}_{2}$, CAT catalyzes $\mathrm{H}_{2} \mathrm{O}_{2}$ dismutation into $\mathrm{H}_{2} \mathrm{O}$ and $\mathrm{O}_{2}$ and GPxs catalyze the reduction of $\mathrm{H}_{2} \mathrm{O}_{2}$ and others hydroperoxides into $\mathrm{H}_{2} \mathrm{O}$ or alcohols. These enzymes are thus an extraordinary source of inspiration for the design of low molecular weight complexes possessing antioxidant properties that could be used as catalytic drugs to supplement these enzymes under pathological situations [3]. Complexes mimicking SOD have attracted much interest since superoxide is the first reactive species in the $\mathrm{O}_{2}$ reduction cascade produced as byproduct during respiration in living aerobic organisms [4-9].

Among the metals used to develop SOD mimics, manganese is the most studied. If released, manganese does not induce Fenton chemistry which would have otherwise led to increased oxidative stress [6,10]. Indeed, to date, a huge diversity of manganese complexes has been reported for their ability to react catalytically with superoxide. They involved ligands such as salen derivatives [11-13], cyclic polyamine [14-19], tri- or dipodal nitrogen-centered ligands [20-24], 1,2-ethanediaminecentered ligands [25-27], desferrioxamine derivatives [15,28,29], polyaminocarboxylato- [30-32] or polycarboxylato ligands [33], peptides [34-36], porphyrins [37-42], phthalocyanines [43], texaphyrins [44,45], corroles [46-48] or biliverdin and its derivatives [49]. Some of these complexes have thus far been assayed on cellular [49-55] and in vivo models [9,53,56-65]. Interestingly, Mn cyclic polyamine $\mathrm{Mn}$ (II) dichloro[(4aR,13aR,17aR,21aR)-1,2,3,4,4a,5,6,12,13,13a, 14,15, 16,17, 17a, 18,19,20,21,21aeicosahydro-11,7-nitrilo-7Hdibenzo[b,h] [1,4,7,10] tetraazacycloheptadecine- $\kappa \mathrm{N} 5, \kappa N 13, \kappa N 18, \kappa N 21$, кN22] (Imisopasem manganese, M40403, CG4419) and Mn porphyrins (Mn(III) meso-tetrakis(N-

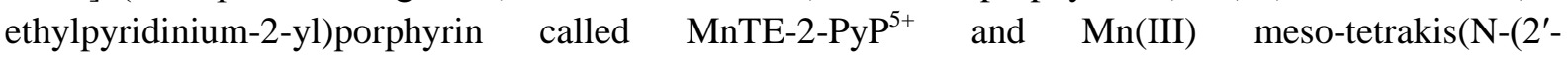

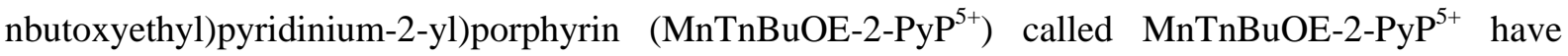
advanced to several clinical trials [66].

The efficiency of the complexes was linked to their intrinsic SOD activity but also to parameters such as cellular uptake, localization inside cells and cellular fragments and their stability. It has been shown that SOD mimics can also exhibit catalase activity and their dual activities have been recently reviewed by Batinic-Haberle et al. and Signorella et al. [5,66-69]. We aimed here to undergo comparative study of several compounds which are frequently tested in cellular and animal models where they showed efficacy ultimately reducing oxidative stress. Small molecules such as those used here do not have protein tertiary structure that would allow specificity for certain reactive species, and thus react with variety of reactive species, both oxidizing or reducing them $[7,5,68,66]$. In particular, studies on Mn porphyrins have demonstrated that these compounds upregulate MnSOD, catalase, glutaredoxins (Grx), peroxiredoxins (Prxs) and other antioxidants via oxidizing cysteine of Kelch-like enoyl-coenzyme A hydratase-associated protein 1 (Keap1) of Nuclear factor erythroid 2-related factor 2 (Nrf2) transcription factor $[68,66,70]$. In that way, rather than acting as SOD and catalase mimics, they indirectly affect levels of $\mathrm{O}_{2}{ }^{--}$and $\mathrm{H}_{2} \mathrm{O}_{2}$.

We used here two assays that are specific for $\mathrm{O}_{2}{ }^{-}$and $\mathrm{H}_{2} \mathrm{O}_{2}$ to see if we can correlate the SOD and CAT like activities of those compounds to their efficacy. For these assays, we have intentionally set up experiments lasting less than $1 \mathrm{~h}$ to focus on the mimics reactivity and to avoid upregulation of antioxidant enzymes. Then, we looked at their efficacy in suppressing the inflammation in HT29-MD2 
cells submitted to bacterial lipopolysaccharide (LPS) challenge. The three cellular assays have been combined with inductively coupled plasma mass spectrometry (ICP-MS) quantification of the Mn center of compounds to get insights into their cell penetration.

\section{Experimental}

\subsection{Reagents and instruments}

LPS (Escherichia coli O55:B5), bovine CuZnSOD, Nicotinamide adenine dinucleotide phosphate (NADH), ferricytochrome $c$ and pyruvic acid were purchased from Sigma Aldrich (Saint-Quentin Fallavier, France). Interleukine-8 (IL-8) detection by enzyme-linked immunosorbent assay (ELISA) was performed using a kit (Duoset) provided by R\&D Systems (Minneapolis, Minnesota, USA). Bicinchoninic acid assay (BCA) and bovine serum albumin (BSA) were from Uptima-Interchim (Montluçon, France). Detection Enhanced Chemiluminescence (ECL) system and nitrocellulose membranes were from Amersham Biosciences (Piscataway, New Jersey, USA). Dulbecco's modified Eagle medium (DMEM), DMEM without $\mathrm{NaHCO}_{3}\left(10\right.$ g.L. $\left.\mathrm{L}^{-1}\right)$ and blasticidin, were from Invitrogen (Thermo Fisher Scientific, Waltham, Massachusetts, USA). Fetal bovine serum (FBS) was from GE Healthcare Life Sciences (South Logan, Utah, USA). (4-(2-hydroxyethyl)-1-piperazineethanesulfonic acid (HEPES) buffer solution (1M), Ethylenediaminetetraacetic acid (EDTA) solution (0.5 M), and Dulbecco's phosphate Buffered Saline (10X, DPBS) were from Gibco (Thermo Fisher Scientific, Waltham, Massachusetts, USA). The protease inhibitor cocktail was from Roche Diagnostics (Meylan, France). Mn Porphyrins were obtained from I. Batinic-Haberle and prepared as detailed in: Rajic Z. et al. for MnTnBuOE-2-PyP [71], Reboucas J.S.R. et al. for Manganese(III) 5,10,15,20-tetrakis(4benzoic acid)porphyrin (MnTBAP) [72], Batinic-Haberle I. et al. for MnTE-2-PyP [73,74]. 2,2,6,6Tetramethyl-4-[[5-(triphenylphosphonio)pentyl]oxy]-1-piperidinyloxy bromide (Mito-Tempol) was purchased from Sigma Aldrich, the enantiomer CG4419 of M40403 from Astatech and Mn(III) 2,2'[1,2-Ethanediylbis(nitrilomethylidyne)]bis[6-methoxy-phenol) (EUK134) from Clinisciences. Mn1 ligand (N-(hydrobenzyl)-N,N'-bis[2-(N-methyl-imidazolyl)methyl]-ethane-1,2-diamine) and complex were synthesized according to previously described protocols [75]. UV-visible spectra were recorded on a Varian Cary 300 Bio spectrophotometer and ICP-MS analysis were performed on an Agilent $7700 \mathrm{X}$.

\subsection{Methods}

\subsubsection{Stock solutions}

Mito-Tempol, M40403 and EUK-134. $5 \mathrm{mM}$ stock solutions in $\mathrm{H}_{2} \mathrm{O}$ were prepared and the compounds were then added to reach the expected incubation concentrations.

Mn1. A $10 \mathrm{mM}$ stock solution of the 1:1 complex was prepared in HEPES (50 mM, pH 7.5). The complex was then added to reach the expected incubation concentrations.

Mn Porphyrins. stock solutions in water were purchased and the compounds were directly added to reach the expected incubation concentrations. $\left[\mathrm{MnTE}-2-\mathrm{PyP}^{5+}\right]=4.5 \mathrm{mM},\left[\mathrm{MnTnBuOE}-2-\mathrm{PyP} \mathrm{P}^{5+}\right]=$ $5.23 \mathrm{mM}$ and $\left[\mathrm{MnTBAP}^{3-}\right]=4.47 \mathrm{mM}$.

\subsubsection{Assay on macrophages}

Cell culture. Murine macrophage RAW 264.7 (American Type Culture Collection) cell line was cultured at $37^{\circ} \mathrm{C}$ under a $5 \% \mathrm{CO}_{2}$ atmosphere in Dulbecco's modified Eagle's medium (DMEM) containing $1.0 \mathrm{~g}$. $\mathrm{L}^{-1} \mathrm{D}$-glucose and sodium pyruvate (Invitrogen). The medium was supplemented with 5\% fetal bovine serum (Invitrogen) and $20 \mu \mathrm{g} . \mathrm{mL}^{-1}$ gentamicin (Sigma).

Viability assay. Cell growth and viability of murine macrophages (RAW 264.7) was assessed by the mitochondrial-dependent reduction of 3-(4,5-dimethylthiazol-2-yl)-2,5-diphenyltetrazolium bromide (MTT) to formazan as previously reported [55]. 
Superoxide measurement. Ferricytochrome c reduction was used to assess the superoxide ion production in RAW 264.7 cells. Cells were stimulated with culture medium containing $1 \mathrm{U} \mathrm{mL}^{-1}$ Interferon gamma (IFN- $\gamma$ ) and $1 \mathrm{ng} \mathrm{mL} \mathrm{L}^{-1} \mathrm{LPS}$ for $24 \mathrm{~h}$ at $37^{\circ} \mathrm{C}$ (except for the negative control). They were then incubated $1 \mathrm{~h}$ at $37^{\circ} \mathrm{C}$ in a home-made medium with $100 \mu \mathrm{M}$ ferricytochrome c (Sigma Aldrich, prepared without using trichloroacid (TCA)), with or without antioxidant and with $800 \mathrm{nM}$ phorbol 12-myristate 13-acetate (PMA). A home-made medium is necessary to get rid of the colored $\mathrm{pH}$ indicator present in DMEM that absorbs in the same range of wavelength as ferricytochrome c. The medium is composed of $14.6 \mathrm{mM}$ glucose, $358 \mathrm{mM} \mathrm{NaCl}, 12.7 \mathrm{mM} \mathrm{KCl}, 3.1 \mathrm{mM} \mathrm{KH}_{2} \mathrm{PO}_{4}, 6.1$ $\mathrm{mM} \mathrm{MgSO}$, $3.1 \mathrm{mM} \mathrm{CaCl} 2,13 \mathrm{mM} \mathrm{NaHCO}_{3}$ and $53 \mathrm{mM}$ HEPES buffer. The absorbance of supernatants was measured at $550 \mathrm{~nm}$, where ferrocytochrome $c$ displays a peak. Contribution of ferricytochrome $c$ at $100 \mu \mathrm{M}$ was subtracted from the absorbance of each sample. This protocol leads to an integration over $1 \mathrm{~h}$ of the production of superoxide in the extracellular medium. Note that this assay was shown to provide a positive result with antioxidants not able to enter cells, such as purified SOD in the extracellular medium [55], with its overall negative charge, as found again here in Figure 2. For that reason, it was labeled "extracellular activity assay" [55], but it most probably provide an activity measurement composite between extracellular and the amount that penetrate in cells during the 1-h incubation.

\subsubsection{Assay on HeLa HyPer cells}

Cell culture. Stable cell line HeLa HyPer1 was prepared using the HeLa Flp-In cell line, which was kindly provided by Stephen Taylor [76], and cultured at $37^{\circ} \mathrm{C}$ under a $5 \% \mathrm{CO}_{2}$ atmosphere in DMEM containing 4.5 g.L ${ }^{-1}$ D-glucose (Invitrogen) supplemented with $10 \%$ of heat-inactivated FBS (Invitrogen). HyPer 1 expression in this stable cell line was controlled by doxycycline, added $24 \mathrm{~h}$ after seeding. The cells were cultured for an additional $24 \mathrm{~h}$ before being processed for analysis. $1 \mathrm{~h}$ before imaging, the medium was replaced by DMEM without $\mathrm{NaHCO}_{3}$ containing 1.0 g.L ${ }^{-1}$ D-glucose and 30 $\mathrm{mM}$ HEPES ( $\mathrm{pH}$ 7.5). This cell is of interest in this context as they endogenously produce $\mathrm{H}_{2} \mathrm{O}_{2}$ a way to evaluate the catalase activity of antioxidants.

Pharmacological treatments. Cells were incubated with or without $100 \mu \mathrm{M}$ of antioxidant during 1 $\mathrm{hr}$ at $37^{\circ} \mathrm{C}$ under a $5 \% \mathrm{CO}_{2}$ atmosphere.

Imaging. Imaging was performed with a CSU-W1 Yokogawa spinning disk coupled to a Zeiss Axio Observer Z1 inverted microscope equipped with a sCMOS Hamamatsu camera and a $63 \times$ objective (63×/1.4 oil WD: $0.17 \mathrm{~mm}$ ) oil objective. DPSS $100 \mathrm{~mW} 405 \mathrm{~nm}$ and $150 \mathrm{~mW} 491 \mathrm{~nm}$ lasers and a $525 / 50$ bandpass emission filter were used.

$\mathrm{H}_{2} \mathrm{O}_{2}$ levels quantification and statistical analysis. Images were processed with the Fiji software, to obtain the HyPer1 ratio of the emission at $530 \mathrm{~nm}(491 / 530) /(405 / 530)$. HyPer ratio was then measured for several cells, and normalized to the ratio value of the control condition. Data were analyzed using Kalaeidagraph and expressed as the mean \pm standard error of the mean (SEM). Statistical significance was calculated using an ordinary one-way ANOVA followed by Tukey's multiple comparison test. Note that this assay was shown to provide a positive result with antioxidants not able to enter cells, such as purified catalase in the extracellular medium [77]. Indeed, $\mathrm{H}_{2} \mathrm{O}_{2}$ is able to cross membranes and its consumption in the extracellular medium shifts the equilibrium and, in fine, consumes also $\mathrm{H}_{2} \mathrm{O}_{2}$ inside cells, where it is measured by the Hyper probe. In this set-up, with a short incubation, the measure is most probably dominated by the extracellular effect, although a contribution of the amount of antioxidants that may have penetrated in cells in $1 \mathrm{~h}$ is not excluded.

1.2.4. Assay on HT29-MD2 cells

Cell culture. HT29 human colon adenocarcinoma were obtained from the European Collection of Authenticated Cell Cultures (ECACC, Wiltshire, UK) and stably transfected to over-express MD2 as 
previously described.[78] Cells were cultured in DMEM supplemented with $10 \%$ of heat-inactivated FBS, and $0.1 \%$ of blasticidin $\left(10 \mu \mathrm{g} \mathrm{mL}^{-1}\right)$ at $37{ }^{\circ} \mathrm{C}$ in a $5 \% \mathrm{CO}_{2} /$ air atmosphere.

Cytotoxicity assay. Cytotoxicity of tested compounds and controls, with LPS, was assessed using lactate dehydrogenase (LDH) release assay, by following the release of the cytosolic lactate dehydrogenase (LDH) into the supernatant, indicating membrane damages [79]. Cytotoxicity was considered when LDH release was more than $10 \%$.

Concentration of LDH in supernatant: $800 \mu \mathrm{L}$ of a pyruvate/NADH solution (see below) was added into a $1 \mathrm{~mL}$ plastic cuvette, as well as $200 \mu \mathrm{L}$ of supernatant, and the decrease in absorbance at 340 $\mathrm{nm}$ was immediately monitored for 1 minute. The slope is proportional to LDH concentration in supernatant.

Concentration of LDH in cell lysate: $800 \mu \mathrm{L}$ of a pyruvate/NADH solution (see below) was added into a $1 \mathrm{~mL}$ plastic cuvette, as well as $190 \mu \mathrm{L}$ of $0.1 \mathrm{M}$ PBS and $10 \mu \mathrm{L}$ of cell lysate, and the decrease in absorbance at $340 \mathrm{~nm}$ was immediately measured for 1 minute. The slope is proportional to LDH concentration in cell lysate.

The percentage of LDH released in the supernatant was calculated as follows:

$$
\% L D H_{\text {released }}=\frac{\text { Slope }_{\text {supernatant }} \times V_{\text {supernatant }} \times 5}{\text { Slope }_{\text {supernatant }} \times V_{\text {supernatant }} \times 5+\text { Slope }_{\text {lysate }} \times V_{\text {lysate }} \times 100} \times 100
$$

Solution of pyruvate/NADH: $4.1 \mathrm{mg}$ of pyruvic acid $(0.62 \mathrm{mM})$, and $7.7 \mathrm{mg}$ of NADH $(0.18 \mathrm{mM})$ in $60 \mathrm{~mL}$ of $0.1 \mathrm{M}$ PBS (pH 7.4).

Cell activation with LPS and incubation with the compounds. HT29-MD2 cells were seeded in 12 or 24 well-plates at 200000 cells/well to reach $90 \%$ confluence after 3 or 4 days. Cells were incubated with media only, or tested compounds at the desired concentration for $6 \mathrm{~h}$ in DMEM supplemented with $10 \%$ of heat-inactivated FBS and with LPS $(0.1 \mu \mathrm{g} / \mathrm{mL})$. Supernatants were collected, and stored at $-20{ }^{\circ} \mathrm{C}$ before ELISA and LDH assay.

Determination of proteins concentrations in cell lysates. In order to normalize the IL-8 concentrations measured, protein content of each cell lysate was measured. They were determined using BCA protein assay reagents and BSA as standard according to the manufacturer's instructions. Briefly, a solution $\left(98 \% \mathrm{BCA}_{2} 2 \% \mathrm{CuSO}_{4}\right)$ was added to the protein solution in 96-wells plate. After $30 \mathrm{~min}$ at $37^{\circ} \mathrm{C}$, the absorbance was monitored at $560 \mathrm{~nm}$ in a SpectraMax M5e microplate reader from Molecular Devices. Absorbance was linked to protein mass thanks to a calibration curve with BSA.

IL8 quantification. Levels of the pro-inflammatory cytokine IL8 produced by cells were determined in cell supernatants using a commercially available ELISA kit according to the instructions of the manufacturer. IL8 levels were normalized by the protein content determined in the corresponding cell lysates.

\subsubsection{Quantification of manganese in cell lysates by ICP-MS}

Cells were cultured in a $75 \mathrm{~cm}^{2}$ plastic flask to reach $90 \%$ confluency. They were incubated with medium only, or tested compounds at the desired concentration for one or twenty-four hours, at $37{ }^{\circ} \mathrm{C}$. Cells were then washed twice with $0.9 \% \mathrm{NaCl} .700 \mu \mathrm{L}$ of HEPES $0.1 \mathrm{M}$ was then added to scratch cells. For HT29-MD2 cells, $50 \mu \mathrm{L}$ of the cell suspension was added to an aqueous solution of $\mathrm{HNO}_{3}$ $2 \%(950 \mu \mathrm{L})$. The resulting solution was heated at $90^{\circ} \mathrm{C}$ overnight to ensure decoordination of $\mathrm{Mn}$ from the porphyrins (Figure S5a, SI). The solution was diluted with a solution of $\mathrm{HNO}_{3} 2 \%(1 \mathrm{~mL})$, filtrated on $0.2 \mu \mathrm{m}$ sized filters to get rid of cellular debris before analysis. A calibration curve was established using anhydrous $\mathrm{MnCl}_{2}$. A range of concentration going from zero to $100 \mathrm{ppb}$ was generally used for calibration. 
For RAW cells, the same above-mentioned procedure was used but using $100 \mu \mathrm{L}$ of the cell suspension in $0.9 \mathrm{~mL}$ of an aqueous solution of $\mathrm{HNO}_{3} 2 \%$.

\subsubsection{Quantification of porphyrins in HT29-MD2 cell lysates by UV-vis spectrometry}

Cells were cultured in a $75 \mathrm{~cm}^{2}$ flask to reach $90 \%$ confluency. They were incubated with medium only, or tested compounds at the desired concentration for one or twenty-four hours, at $37{ }^{\circ} \mathrm{C}$. Cells were then washed twice with $0.9 \% \mathrm{NaCl} .700 \mu \mathrm{L}$ of HEPES $0.1 \mathrm{M}$ was then added to scratch cells. Cells were lysed by sonication. UV-vis spectra of the resulting solutions were recorded and the spectrum of a solution of non-incubated cell was subtracted to get rid of the cell absorption. The absorbance of the Soret band was compared with those of solutions $(5 \mu \mathrm{M})$ of the pure porphyrins in water. To compare the concentrations found by UV-vis with the concentrations measured by ICP-MS, the concentrations in $\mu \mathrm{M}$ were converted into ppb considering the dilution used for samples preparation in ICP-MS experiments (dilution $\times 40$ ).

\section{Results and discussion}

A nitroxide radical (Mito-TEMPOL) and several MnSOD mimics (Figure 1) belonging to the above-mentioned SOD mimics families, covering a large range of SOD activity and/or catalase activity were selected (Table 1). Mito-TEMPOL was included for comparison, since it does not involve a metal cation to perform the redox catalysis, does not exhibit catalase activity but shows a weak SOD activity only in acidic region $[8,67]$. The catalysis of superoxide dismutation occurs via redox couple $\mathrm{RNO}^{\bullet} / \mathrm{RNO}^{+}$[80]. In addition, Mito-TEMPOL, possesses a triphenylphosphonium group to increase its accumulation into mitochondria where reactive oxygen species (ROS) are mainly produced [81]. Among the Mn porphyrins studied, two positively charged and differently lipophilic $\left(\mathrm{MnTE}-2-\mathrm{PyP}^{5+}\right.$ and $\mathrm{MnTnBuOE}-2-\mathrm{PyP}^{5+}$ ) and one negatively charged $\left(\mathrm{MnTBAP}^{3-}\right.$ ) have been selected. The positively charged Mn porphyrins were shown to enter the cell, where they prefer nucleus and mitochondria being driven there by anionic phosphate groups and mitochondrial negative potential $[5,70,82,83]$. It is expected that the negatively charged porphyrin will be less reactive towards the negatively charged superoxide and less cell penetrant.

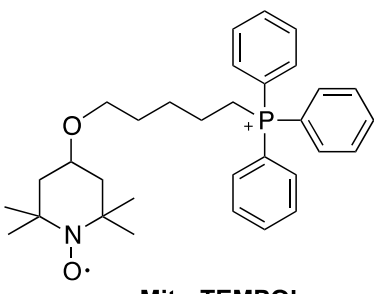

Mito-TEMPOL

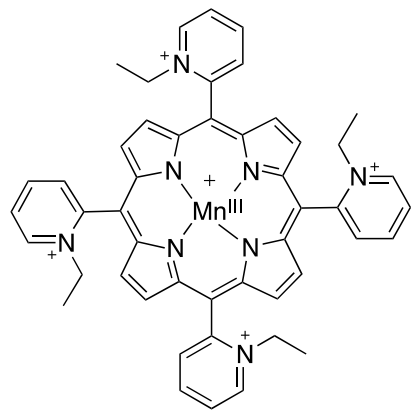

MnTE-2-PyP ${ }^{5+}$

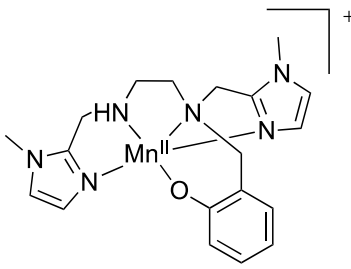

Mn1
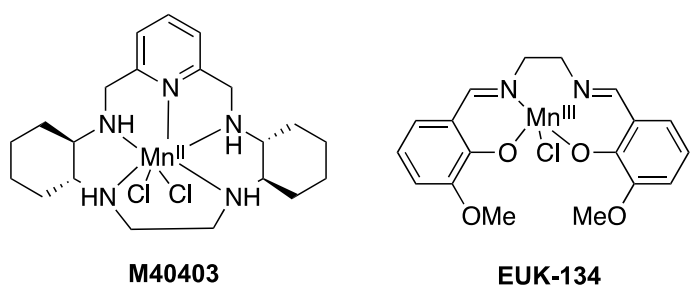

EUK-134
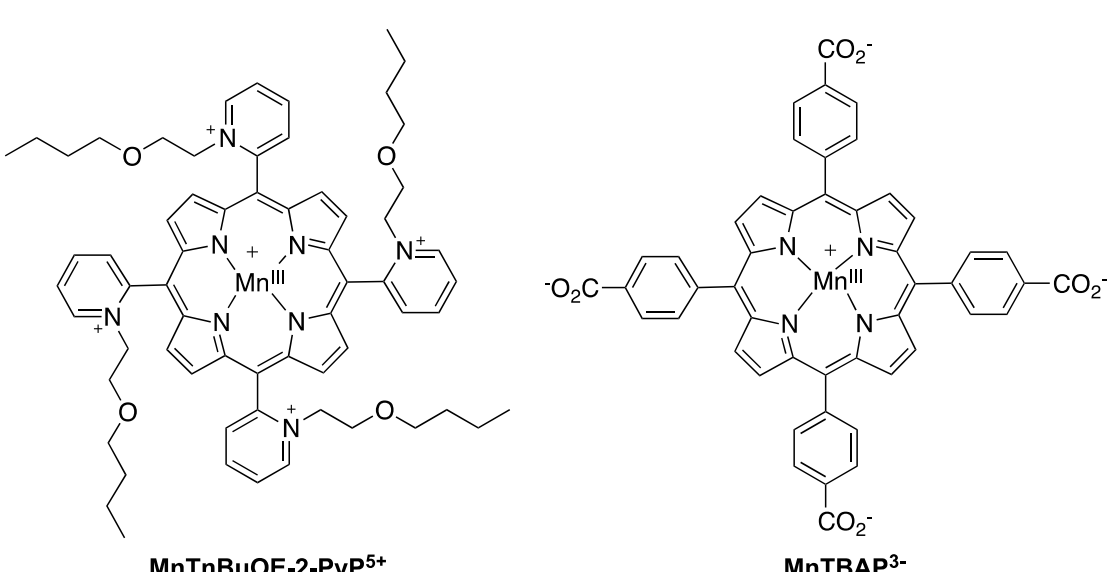

MnTBAP ${ }^{3-}$

Figure 1. Structure of the selected antioxidants studied in this article. 


\begin{tabular}{|c|c|c|c|c|}
\hline & \multicolumn{2}{|c|}{ SOD activity } & \multirow{2}{*}{$\begin{array}{c}\text { CAT activity } \\
k_{\text {cat }} \mathrm{H}_{2} \mathrm{O}_{2}\left(\mathrm{M}^{-1} \mathrm{~s}^{-1}\right)^{\mathrm{f}}\end{array}$} & \multirow[b]{2}{*}{ references } \\
\hline & $k_{\mathrm{McCF}}\left(10^{6} \mathrm{M}^{-1} \mathrm{~s}^{-1}\right)$ & $k_{\text {cat }}\left(10^{6} \mathrm{M}^{-1} \mathrm{~s}^{-1}\right)$ & & \\
\hline Mito-TEMPOL & $0.0297^{\mathrm{a}}$ & & none & {$[84]$} \\
\hline Mn1 & $7.0^{\mathrm{b}}$ & $6.2^{\mathrm{c}} \mathrm{SF}$ & $2.3^{\mathrm{g}}$ & {$[75],[85],[55]$} \\
\hline M40403 & $3.55^{\mathrm{b}}$ & $1.9^{\mathrm{d}} \mathrm{SF}$ & 8.2 & {$[7],[86],[67]$} \\
\hline EUK-134 & $0.602^{\mathrm{b}}$ & & $13.0^{\mathrm{h}}$ & {$[52],[67],[87]$} \\
\hline MnTE-2-PyP $\mathrm{P}^{5+}$ & $57^{\mathrm{b}}$ & $54 \mathrm{PR}$ & 63.3 & {$[73],[67]$} \\
\hline MnTnBuOE-2-PyP ${ }^{5+}$ & $68^{\mathrm{b}}$ & & 88.5 & {$[5],[67]$} \\
\hline $\mathrm{MnTBAP}^{3-}$ & $0.00145^{\mathrm{b}}$ & none ${ }^{\mathrm{d}} \mathrm{SF}$ & 5.8 & {$[86],[72],[67]$} \\
\hline $\mathrm{MnCl}_{2}$ & $1.3^{\mathrm{b}}$ & $1.9^{\mathrm{b}} \mathrm{PR}$ & none & {$[49],[88],[86]$} \\
\hline $\mathrm{Mn}\left(\mathrm{ClO}_{4}\right)_{2}$ & $1.3^{\mathrm{b}}$ & & & {$[23,89]$} \\
\hline CuZnSOD & $692-1995^{\mathrm{b}}$ & $2000^{\mathrm{e}} \mathrm{SF}$ & & {$[86],[90],[91],[92]$} \\
\hline MnSOD & & ca. $3000 \mathrm{PR}$ & & [93] \\
\hline Catalase from bovine liver & & & $1.510^{6}$ & [67] \\
\hline
\end{tabular}

Table 1. Antioxidants intrinsic dismutation constants. $k_{\mathrm{McCF}}$ refers to the rate constant calculated from the McCord and Fridovich assay. ${ }^{a}$ Ferricytochrome c, phosphate buffer $(50 \mathrm{mM}, \mathrm{pH} 8) .{ }^{\mathrm{b}}$ Ferricytochrome $c$, phosphate buffer (50 mM, pH 7.8). ${ }^{\mathrm{c}}$ HEPES (60 mM, pH 7.4). ${ }^{\mathrm{d}}$ Phosphate buffer (50 mM, pH 7.4). ${ }^{\mathrm{e}}$ Phosphate buffer (50 mM, pH 7.8). ${ }^{\mathrm{f}}$ Unless specified, catalytic constants were measured by polarography using a Clarktype electrode in tris(hydroxymethyl)aminomethane (Tris) buffer (50 mM, pH 7.8). ${ }^{\mathrm{g}} \mathrm{HEPES}(100 \mathrm{mM}, \mathrm{pH} 7.4)$. ${ }^{\mathrm{h}}$ Value found for EUK-8 instead of EUK-134 that differs only by the two methoxy substituents. SF means stopped-flow and PR pulse radiolysis.

While not reported as not being a catalytic SOD mimic [94], MnTBAP ${ }^{3-}$ can be interesting as it reacts with peroxynitrite and has reportedly shown efficacy in vitro and in vivo [8,95,96]. We refer herein as intrinsic activities to the kinetics of the reaction with superoxide or hydrogen peroxide outside of any cellular context, whether it is catalytic or not, typically reported in Table 1 [6].

In order to compare the antioxidants selected for their SOD activity in cells, we have first used an assay involving murine macrophages RAW 264.7 [55]. On this cell line, the production of RS including superoxide can be induced upon stimulation with bacterial lipopolysaccharide (LPS) and interferon $\gamma$ (IFN- $\gamma)$. The release of these RS in the surrounding medium is then triggered using phorbol 12-myristate 13-acetate (PMA) [54,55,97]. Quantification of superoxide concentration is made possible by using ferricytochrome $c$ as superoxide UV-vis marker. As ferricytochrome $c$ is not able to penetrate cells, only the superoxide released extracellularly is measured. CuZnSOD was incubated at $100 \mathrm{U} / \mathrm{mL}$ and all of the other antioxidants were incubated, in presence of ferricytochrome $c$, for $1 \mathrm{~h}$ at $5 \mu \mathrm{M}$. At this concentration, no toxicity was observed (MTT assay, Figure $\mathrm{S} 1, \mathrm{SI})$. It is worth mentioning that $1 \mathrm{~h}$-inccubation may be too short to lead to antioxidant proteins upregulation [98]. In presence of superoxide, the ferricytochrome $c$ is reduced into ferrocytochrome $c$. A SOD mimic competes with ferricytochrome $c$ for reaction with superoxide and leads to a lowering of the amount in ferrocytochrome $c$. The ferrocytochrome $c$ concentrations measured in the cell supernatants were compared and the concentration found after activation and in absence of any antioxidant was set at $100 \%$. Of note, even if the superoxide concentration is measured outside the cells, an antioxidant that enters cells and decreases superoxide concentration inside cells would also result in lowering ferricytochrome $c$ reduction [55]. As shown in Figure 2, three main groups emerged: very efficient catalysts (\% ferricytochrome $c<20 \%$ activated), efficient catalysts $(20 \%<$ $\%$ ferricytochrome $c<80 \%$ activated), and inactive catalysts (\% ferricytochrome $c>80 \%$ activated). In the first group, the recombinant $\mathrm{CuZnSOD}$ is very efficient at reducing the extracellular superoxide 
concentration and was even able to result in superoxide levels lower than that obtained for nonactivated cells. In the second group, Mn1, M40403, EUK-134 and the two positively charged porphyrins MnTE-2-PyP ${ }^{5+}$ and $\mathrm{MnTnBuOE}-2-\mathrm{PyP}^{5+}$ were able to decrease the extracellular superoxide concentrations to levels close to the non-activated situation. With exception of EUK-134, such data reflect their similar SOD-like activities. In the third group, Mito-TEMPOL and MnTBAP ${ }^{3-}$ were found inactive in the tested conditions.

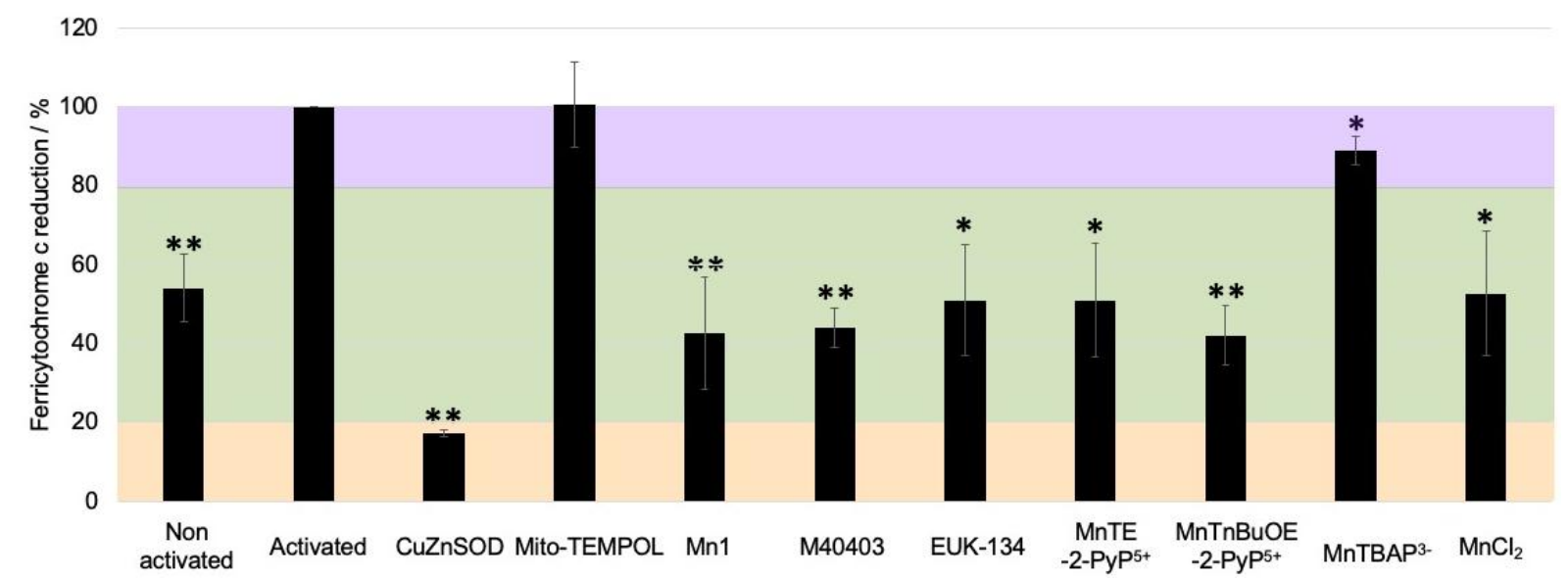

Figure 2. Evaluation of antioxidants on murine macrophages RAW 264.7. Reported values are related to the values observed for activated cells and arbitrarily set at $100 \%$. Macrophages were incubated with IFN- $\gamma(1 \mathrm{U}$ $\left.\mathrm{mL}^{-1}\right)$ and LPS $\left(1 \mathrm{ng} \mathrm{mL}^{-1}\right)$ for $24 \mathrm{~h}$ at $37^{\circ} \mathrm{C}$ in DMEM followed by an incubation with ferricytochrome $c(100$ $\mu \mathrm{M})$, PMA $(800 \mathrm{nM})$ and antioxidants $(100 \mu \mathrm{M})$ at $37^{\circ} \mathrm{C}$ for $1 \mathrm{~h}$ in a homemade medium (see experimental section). Data are mean \pm SEM of three independent experiments with $(* *) p<0.01$ and $(*) p<0.05$ versus activated cells.

As expected, the obtained results are in line with the lack of their SOD activities reported in Table 1 ( $k_{\mathrm{McCF}}$ or $\left.k_{\mathrm{cat}}\right)$. Both compounds have SOD-like activities lower than the rate for $\mathrm{O}_{2}{ }^{-}$selfdismutation of $\sim 5 \times 10^{5} \mathrm{M}^{-1} \mathrm{~s}^{-1}$ and are thus not true catalytic SOD mimics [7].

In a second assay, we wanted to compare the antioxidants according to their catalase activity. We have used HeLa cells expressing intracellularly the ratiometric fluorescent sensor of $\mathrm{H}_{2} \mathrm{O}_{2}$ called HyPer [99]. HyPer is a circularly permuted yellow fluorescent protein (cpYFP) emitting at $530 \mathrm{~nm}$ integrated into the regulatory domain of the bacterial $\mathrm{H}_{2} \mathrm{O}_{2}$ sensing protein OxyR (OxyR-RD). Upon oxidation of HyPer thiols by $\mathrm{H}_{2} \mathrm{O}_{2}$, disulfide bridges formation induces a modification of the spectral properties of the YFP. This leads to a ratiometric modification of the excitation spectrum of HyPer that possesses two excitation maxima at 420 and $488 \mathrm{~nm}$. Thus, by measuring the normalized ratio of the intensity $\mathrm{I}_{(491 / 530)} / \mathrm{I}_{(405 / 530)}$, it is possible to monitor specifically $\mathrm{H}_{2} \mathrm{O}_{2}$ concentration in cells. It is worth mentioning that since $\mathrm{H}_{2} \mathrm{O}_{2}$ is able to passively diffuse across cytoplasmic membrane, the observed effect of the antioxidants may be composite: it may be due to dismutation of $\mathrm{H}_{2} \mathrm{O}_{2}$ inside or outside the cells. For instance, incubation of HeLa HyPer with the recombinant heme catalase, has shown to reduce $\mathrm{H}_{2} \mathrm{O}_{2}$ concentration inside cells whereas it does not cross cells membrane [77].

HeLa HyPer cells were incubated with the antioxidants for $1 \mathrm{~h}$ at $100 \mu \mathrm{M}$ in HEPES buffer and imaged at $530 \mathrm{~nm}$ by fluorescence microscopy upon excitation at two wavelengths 405 and $491 \mathrm{~nm}$ respectively (Figures S2 and S3) [100]. This incubation time is long enough to detect an effect on $\mathrm{H}_{2} \mathrm{O}_{2}$ concentration and short enough to exclude a possible feedback of the cell expressing antioxidant enzymes [98]. Hence, this assay is meant to evidence a direct effect of the compounds to reduce the level of $\mathrm{H}_{2} \mathrm{O}_{2}$. The ratios of the intensity $\mathrm{I}_{(491 / 530)} / \mathrm{I}_{(405 / 530)}$ normalized against the control (NFR for normalized fluorescence ratio) was determined for several cells (typically 50-150 cells) and 
were reported in the Figure 3. In this assay, cells were not stressed, and, consequently, the effects reported are those on basal $\mathrm{H}_{2} \mathrm{O}_{2}$ levels.

As shown in Figure 3, again, three groups of antioxidants were observed: efficacious catalyst $(0.5$ $<$ NFR < 0.75), moderately efficacious catalysts $(0.75<$ NFR < 1$)$ and prooxidant compounds (NFR > 1). In the first group, the two more efficacious CAT mimics from aqueous chemistry studies were MnTE-2-PyP ${ }^{5+}\left(\mathrm{k}_{\mathrm{cat}} \mathrm{H}_{2} \mathrm{O}_{2}=63.3 \mathrm{M}^{-1} \mathrm{~s}^{-1}\right)$ [67] and MnTnBuOE-2-PyP ${ }^{5+}\left(\mathrm{k}_{\mathrm{cat}} \mathrm{H}_{2} \mathrm{O}_{2}=88.5 \mathrm{M}^{-1} \mathrm{~s}^{-1}\right)$ [67] and were indeed found with NFR of 0.68 and 0.60 respectively. The effect of MnTnBuOE-2-Pyp ${ }^{5+}$ may be higher as it distributes to a higher level to cells than does MnTE-2-PyP ${ }^{5+}$ [68]. In the second group, $\mathrm{Mn} 1$ and EUK-134 reduced similarly the $\mathrm{H}_{2} \mathrm{O}_{2}$ concentration in HeLa cells which correlates with their similar moderate intrinsic CAT activities (2.3 and $13 \mathrm{M}^{-1} \mathrm{~s}^{-1}$ respectively) [55,67,87]. Surprisingly, Mito-TEMPOL was found active in this assay whereas no CAT activity is reported for this compound. In contrast, although M40403 exhibits a CAT activity $\left(8.2 \mathrm{M}^{-1} \mathrm{~s}^{-1}\right)$ similar to Mn1 and EUK-134 in aqueous studies, in cells, M40403 induced increased levels of $\mathrm{H}_{2} \mathrm{O}_{2}$ [67]. In eukaryotic organisms, the steady state concentration of superoxide and $\mathrm{H}_{2} \mathrm{O}_{2}$ were estimated to be $10^{-10}$ and $5010^{-10} \mathrm{M}$ respectively, attesting the higher tolerance of eukaryotic cells for $\mathrm{H}_{2} \mathrm{O}_{2}$ than for $\mathrm{O}_{2}{ }^{-}$[101]. Owing to this ratio, it is very unlikely that by catalyzing superoxide dismutation the antioxidants lead to a measurable increase of $\mathrm{H}_{2} \mathrm{O}_{2}$ concentration and thus to an increased fluorescence ratio. The increased level of $\mathrm{H}_{2} \mathrm{O}_{2}$ observed with M40403 may instead be due to a low stability of the complexes which may partly dissociate and lead to manganese release as reported recently [102,103]; there may be a ligand chemistry or toxicity we are still not aware of and would require further studies. Increased levels of $\mathrm{H}_{2} \mathrm{O}_{2}$ were also observed after incubation with the redox silent analogue of Mn1 called $\mathrm{Zn} 1$ and the manganese salt $\mathrm{MnCl}_{2}$.The negatively charged porphyrin $\mathrm{MnTBAP}^{3-}$ did not show a significant effect on $\mathrm{H}_{2} \mathrm{O}_{2}$ concentration as it has no CAT-like activity. Overall, as $\mathrm{H}_{2} \mathrm{O}_{2}$ is mainly produced at the plasma membrane and can easily diffuse, and as the results are in line with the catalytic constants measured in test tubes with the positively charged porphyrins being the most efficacious [104], these results suggest that the measured activities are mainly due to the portion of antioxidants that remain outside the cells.

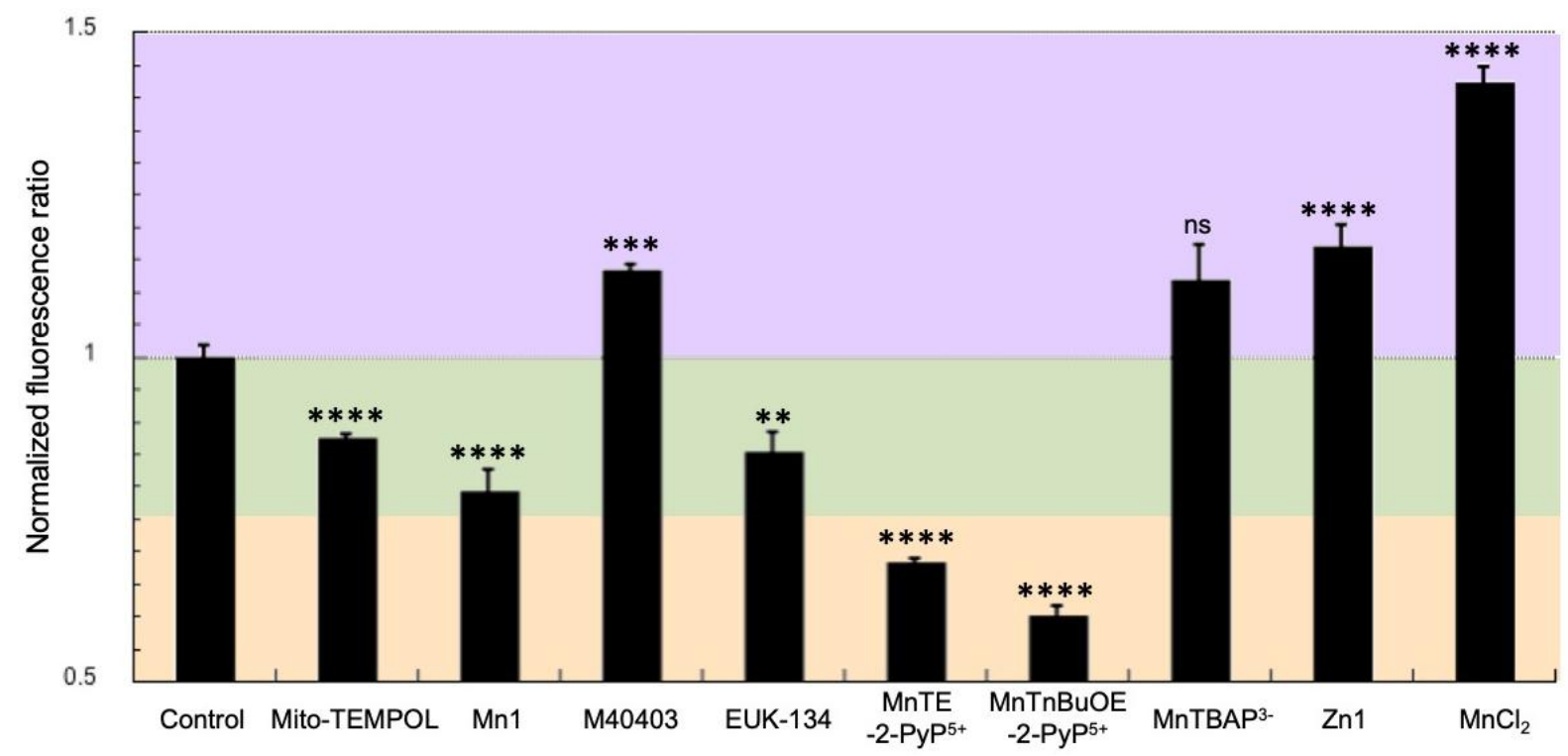

Figure 3. $\mathrm{H}_{2} \mathrm{O}_{2}$ levels measured in HyPer HeLa cells. The cells were incubated $1 \mathrm{~h}$ at $37^{\circ} \mathrm{C}$ in HEPES $(30 \mathrm{mM}$ $\mathrm{pH}$ 7.5) under $5 \% \mathrm{CO}_{2}$ without (control) or with antioxidants at $100 \mu \mathrm{M}$. Fluorescence images were recorded after excitation at $405 \mathrm{~nm}$ and $491 \mathrm{~nm}$ and the ratio of the emission at $530 \mathrm{~nm} \mathrm{I} \mathrm{I}_{(491 / 530)} / \mathrm{I}_{(405 / 530)}$ was measured for several cells. The ratio was arbitrarily set at 1 for control cells i.e. cells incubated with HEPES only. Data are 
mean \pm SEM of several cells (from 48 to 163 cells) with $* * * * p<0.0001, * * * p<0.001$, ** $\mathrm{p}<0.01$ and $* \mathrm{p}<$ 0.05 vs. control cells. ns means non-significant.

To go further, we have assayed the selected antioxidants on HT29-MD2 cells. These intestine epithelial cells have been stably transfected to overexpress MD2 protein that promotes an enhanced inflammatory response in presence of bacterial lipopolysaccharide [78]. Besides, it has been shown that such inflammatory reaction is mediated by oxidative stress [105,106]. HT29-MD2 cells were thus incubated in presence of LPS and the antioxidants at non-toxic concentrations: 10 and $100 \mu \mathrm{M}$ (Figure S4, SI) $[9,103,107]$. In this assay, $6 \mathrm{~h}$ incubations were required to observe a significant inflammatory response. Consequently, the observed anti-inflammatory effect of the antioxidants may be related to either their direct scavenging of $\mathrm{O}_{2}{ }^{--}$or $\mathrm{H}_{2} \mathrm{O}_{2}$, or mediated metabolic processes that would result in reducing levels of those species and oxidative stress in general. The concentration of an inflammatory marker, the interleukin 8 (IL8) has been measured by ELISA to compare the effects of the antioxidants. As expected, upon LPS challenge, the IL8 concentration of non-incubated cells increased significantly. Thus, the decreased level of IL8 in the presence of an antioxidant was indicative of antiinflammatory activity (Figure 4). After incubation of the antioxidants at $10 \mu \mathrm{M}$, only M40403, and MnTnBuOE-2-PyP ${ }^{5+}$ to a lesser extent, showed a moderate anti-inflammatory effect. The other compounds were found inactive or even pro-inflammatory in the case of $\mathrm{Mn} 1$. Taking into account $\mathrm{Mn} 1$ dissociation constant in solution that has been estimated to be $6.5 \pm 1.710^{-7} \mathrm{M}$ [85], at a concentration of $10 \mu \mathrm{M}$, it is expected that at least $23 \%$ of the ligand is not coordinated to $\mathrm{Mn}$ and this value may increase in a competitive ligand biological environment. Because the ligand is toxic for the cells [9], the pro-inflammatory response observed may be due to the toxicity of the non-coordinated ligand. Note that in this model, $\mathrm{MnCl}_{2}$ was previously assayed and found to be not active or proinflammatory [9,103,107]. After incubation at a higher concentration $(100 \mu \mathrm{M})$, as expected, M40403 and $\mathrm{MnTnBuOE}-2-\mathrm{PyP}^{5+}$ were found more active than at $10 \mu \mathrm{M} . \mathrm{Mn} 1$ also exhibited high antiinflammatory effect as already reported [9]. Surprisingly, MnTE-2-PyP ${ }^{5+}$ did not lead to a significant decrease of IL8 level whereas it possesses similar catalytic constants for superoxide and $\mathrm{H}_{2} \mathrm{O}_{2}$ dismutation as MnTnBuOE-2-PyP ${ }^{5+}[68]$.

The bioavailability of cationic Mn-porphyrins in cellular fragments, cells and tissue has been comprehensively studied and reported [70]. In this cellular assay, we observed that both the more hydrophilic MnTE-2-PyP ${ }^{5+}$ and MnTnBuOE-2-PyP $\mathrm{P}^{5+}$ penetrate similarly, as shown by quantification of the Mn content by ICP-MS in cell lysates incubated with these porphyrins that lead to similar values (Figure S6, SI). A similar trend was observed when the porphyrins were quantified in cell lysates using their specific UV-Vis signature (Figure S5 b-c and Figure S6, SI). To note, very surprisingly, quantification experiments showed that the negatively charged $\mathrm{MnTBAP}^{3-}$ was more internalized than the positively charged porphyrins (Figure S5 b-c and Figure S6, SI), which was not expected. It should however be mentioned that $\mathrm{MnTBAP}^{3-}$ was suggested to display an intracellular and intramitochondrial bio-activity [108]. Although it penetrates in this model, no activity was observed for this negatively charged porphyrin. Interestingly too, this study suggests that M40403 and EUK134 penetrate into cells and confirmed the previous results reported for Mn1 [9,103,107]. The different activities observed here may be related to different cellular localizations. In this assay, antioxidants that are poor SOD mimics (MITO-TEMPOL, EUK-134, MnTBAP ${ }^{3-}$ ) are not efficient whatever their catalase-like activity, suggesting that superoxide and/or its progeny may be the main reactive species that had to be controlled in this model and played an important role in the inflammatory responses. While inferior at lower $10 \mu \mathrm{M}$ concentration, due to its low metal-ligand stability and/or inertia, at $100 \mu \mathrm{M}$, though, Mn1 showed the best anti-inflammatory activity in this cellular model, likely due to its high SOD activity and high bioavailability. 


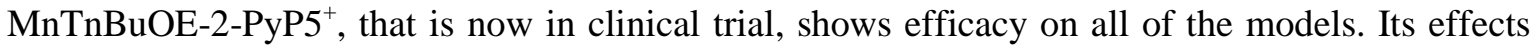
may be due to direct scavenging of $\mathrm{H}_{2} \mathrm{O}_{2}$ and $\mathrm{O}_{2}{ }^{-}$(for the two first cellular models, with short incubation times) and/or to the Mn porphyrin-driven upregulation of MnSOD and catalase that would then take care of $\mathrm{H}_{2} \mathrm{O}_{2}$ and $\mathrm{O}_{2}^{-}$(inflammation model requiring a longer $6 \mathrm{~h}$ incubation, compatible with protein up-regulation). These data support its progress into clinical [66,109].

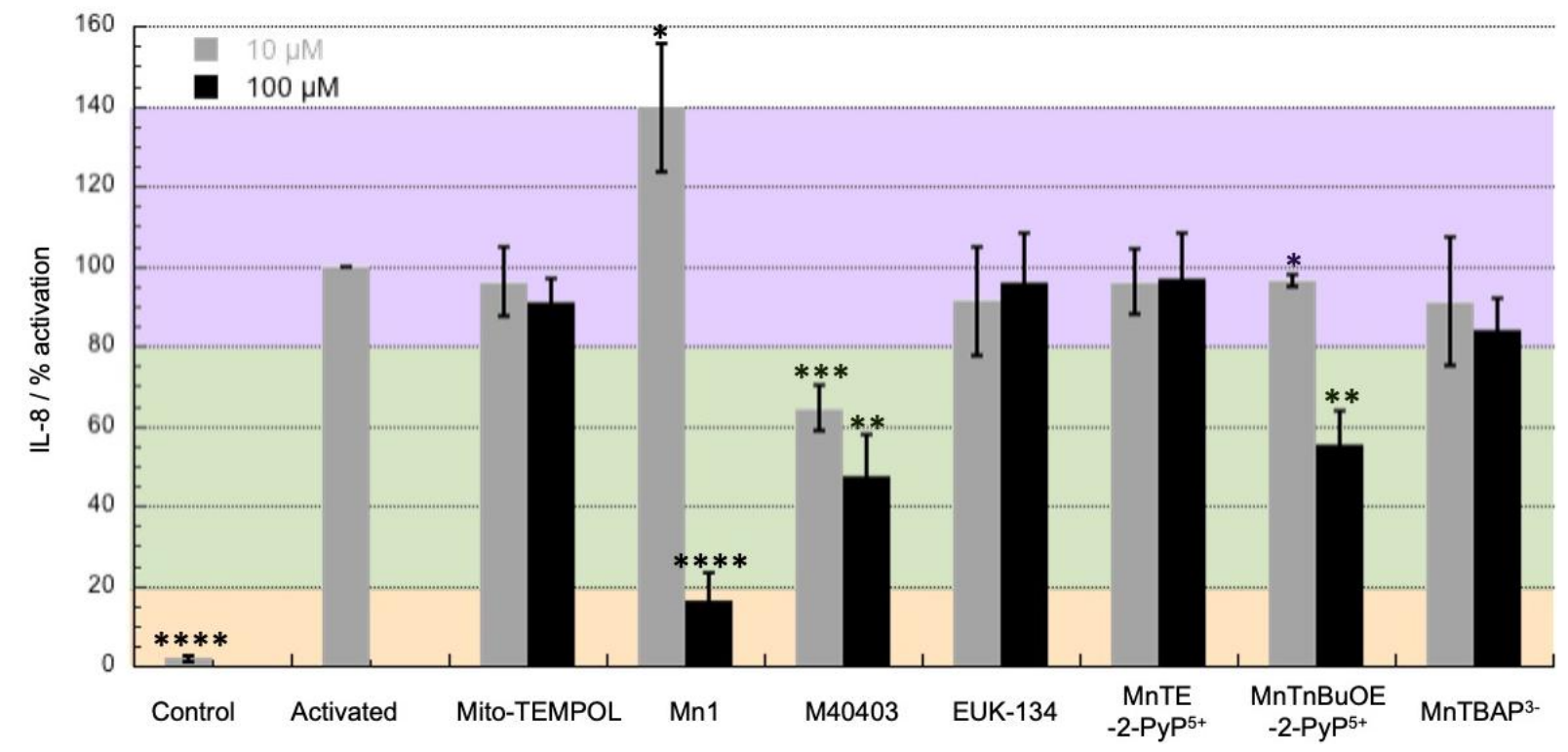

Figure 4. Quantification of the inflammatory marker IL8 by ELISA after incubation of HT29-MD2 cells with the antioxidants at 10 or $100 \mu \mathrm{M}$. Antioxidants were incubated for $6 \mathrm{~h}$ at $37^{\circ} \mathrm{C}$ in supplemented DMEM in presence of LPS $\left(0.1 \mu \mathrm{g} \mathrm{mL}^{-1}\right)$ except for the control where no antioxidants and LPS were added. The absorbance measured for activated cells was arbitrary set at $100 \%$. Data represent mean \pm SEM for two independent experiments for MnTnBuOE-2-PyP ${ }^{5+}$ and M40403 and three independent experiments for MitoTEMPOL, Mn1, EUK-134, MnTE-2-PyP ${ }^{5+}$ and MnTBAP $^{3-}$ with $* * * * \mathrm{p}<0.0001, * * * \mathrm{p}<0.001$, ** $\mathrm{p}<0.01$ and $* \mathrm{p}<0.05$ vs. activated cells.

\section{Conclusion}

In conclusion, we have shown that the assays on macrophages (for SOD activity) and on HeLa HyPer cells (for CAT activity) are useful to validate the activity of antioxidants in cellular contexts. They allow verifying that the compounds are efficient under biological conditions which data justify their further evaluation under more complex conditions. The assay on HT29-MD2 cells affords more relevant information, in particular for SOD mimics, since in this assay, among the ROS produced, it seems that superoxide or its progeny plays an important role in the inflammatory response of the cells. The bioactivities measured were related not only to the intrinsic catalytic activities of the antioxidants but also with their penetration inside the cells. Evidences suggested that their cellular localization is also an important factor; this assay gained an insight into their bioavailabilities. This three-cell-model assay thus provides a comparison of different families of SOD mimics on cellular models relevant for the development of such compounds, and a broader overview of the potential of antioxidants for their use as catalytic drugs.

\section{Acknowledgments}


We thank Ecole Normale Supérieure Paris Saclay for A. Vincent's PhD fellowship, TGE RENARD (FR 3443, CNRS) and UMR8601 and S. Lajnef for access to the EPR spectrometer for the EPR experiments. We also thank B. Goetz and P. Legeay for help with ICP-MS. ANR (ANR-15-CE070027), Association François Aupetit and the Fondation pour la Recherche Biomédicale (project DIE20151234413) are acknowledged for financial supports.

\section{References}

[1] B. Halliwell, J.M.C. Gutteridge, Free radicals in biology and medicine, Fifth, Oxford University Press, New York, NY, 2015.

[2] R.L. Auten, J.M. Davis, Oxygen toxicity and reactive oxygen species: the devil is in the details, Pediatr. Res. 66 (2009) 121-127. https://doi.org/10.1203/PDR.0b013e3181a9eafb.

[3] J.J. Soldevila-Barreda, P.J. Sadler, Approaches to the design of catalytic metallodrugs, Current Opinion in Chemical Biology. 25 (2015) 172-183. https://doi.org/10.1016/j.cbpa.2015.01.024.

[4] O. Iranzo, Manganese complexes displaying superoxide dismutase activity: A balance between different factors, Bioorganic Chemistry. 39 (2011) 73-87. https://doi.org/10.1016/j.bioorg.2011.02.001.

[5] I. Batinic-Haberle, A. Tovmasyan, E.R.H. Roberts, Z. Vujaskovic, K.W. Leong, I. Spasojevic, SOD Therapeutics: Latest Insights into Their Structure-Activity Relationships and Impact on the Cellular Redox-Based Signaling Pathways, Antioxid Redox Signal. 20 (2014) 2372-2415. https://doi.org/10.1089/ars.2012.5147.

[6] C. Policar, Mimicking SODs, Why and How: Bio-Inspired Manganese Complexes as SOD Mimics, in: Redox-Active Therapeutics, Springer Science, New York, NY, 2016: pp. $125-164$.

[7] I. Batinić-Haberle, J.S. Rebouças, I. Spasojević, Superoxide Dismutase Mimics: Chemistry, Pharmacology, and Therapeutic Potential, Antioxid Redox Signal. 13 (2010) 877-918. https://doi.org/10.1089/ars.2009.2876.

[8] S. Miriyala, I. Spasojevic, A. Tovmasyan, D. Salvemini, Z. Vujaskovic, D. St. Clair, I. Batinic-Haberle, Manganese superoxide dismutase, MnSOD and its mimics, Biochimica et Biophysica Acta (BBA) - Molecular Basis of Disease. 1822 (2012) 794 814. https://doi.org/10.1016/j.bbadis.2011.12.002.

[9] E. Mathieu, A.-S. Bernard, N. Delsuc, E. Quévrain, G. Gazzah, B. Lai, F. Chain, P. Langella, M. Bachelet, J. Masliah, P. Seksik, C. Policar, A Cell-Penetrant Manganese Superoxide Dismutase (MnSOD) Mimic Is Able To Complement MnSOD and Exerts an Antiinflammatory Effect on Cellular and Animal Models of Inflammatory Bowel Diseases, Inorganic Chemistry. 56 (2017) 2545-2555. https://doi.org/10.1021/acs.inorgchem.6b02695.

[10] J.G. Charrier, C. Anastasio, On dithiothreitol (DTT) as a measure of oxidative potential for ambient particles: evidence for the importance of soluble transition metals, Atmos Chem Phys. 12 (2012) 11317-11350. https://doi.org/10.5194/acpd-12-11317-2012.

[11] M. Baudry, S. Etienne, A. Bruce, M. Palucki, E. Jacobsen, B. Malfroy, Salenmanganese complexes are superoxide dismutase-mimics, Biochem. Biophys. Res. Commun. 192 (1993) 964-968. https://doi.org/10.1006/bbrc.1993.1509.

[12] A. Puglisi, G. Tabbì, G. Vecchio, Bioconjugates of cyclodextrins of manganese salentype ligand with superoxide dismutase activity, Journal of Inorganic Biochemistry. 98 (2004) 969-976. https://doi.org/10.1016/j.jinorgbio.2004.02.012. 
[13] W. Park, D. Lim, Effect of the oligo(ethylene glycol) group on the antioxidant activity of manganese salen complexes, Bioorganic \& Medicinal Chemistry Letters. 19 (2009) 614-617. https://doi.org/10.1016/j.bmcl.2008.12.063.

[14] D. Salvemini, C. Muscoli, D.P. Riley, S. Cuzzocrea, Superoxide Dismutase Mimetics, Pulmonary Pharmacology \& Therapeutics. 15 (2002) 439-447. https://doi.org/10.1006/pupt.2002.0374.

[15] J.D. Rush, Z. Maskos, W.H. Koppenol, The superoxide dismutase activities of two higher-valent manganese complexes, MnIV desferrioxamine and MnIII cyclam, Archives of Biochemistry and Biophysics. 289 (1991) 97-102. https://doi.org/10.1016/0003-9861(91)90447-Q.

[16] D.P. Riley, R.H. Weiss, Manganese macrocyclic ligand complexes as mimics of superoxide dismutase, J. Am. Chem. Soc. 116 (1994) 387-388. https://doi.org/10.1021/ja00080a051.

[17] D.P. Riley, S.L. Henke, P.J. Lennon, K. Aston, Computer-Aided Design (CAD) of Synzymes: Use of Molecular Mechanics (MM) for the Rational Design of Superoxide Dismutase Mimics, Inorg. Chem. 38 (1999) 1908-1917. https://doi.org/10.1021/ic981319b.

[18] D. Salvemini, Z.-Q. Wang, J.L. Zweier, A. Samouilov, H. Macarthur, T.P. Misko, M.G. Currie, S. Cuzzocrea, J.A. Sikorski, D.P. Riley, A Nonpeptidyl Mimic of Superoxide Dismutase with Therapeutic Activity in Rats, Science. 286 (1999) 304-306. https://doi.org/10.1126/science.286.5438.304.

[19] A. Dees, A. Zahl, R. Puchta, N.J.R. van Eikema Hommes, F.W. Heinemann, I. Ivanović-Burmazović, Water Exchange on Seven-Coordinate Mn(II) Complexes with Macrocyclic Pentadentate Ligands: Insight in the Mechanism of Mn(II) SOD Mimetics, Inorg. Chem. 46 (2007) 2459-2470. https://doi.org/10.1021/ic061852o.

[20] N. Kitajima, M. Osawa, N. Tamura, Y. Morooka, T. Hirano, M. Hirobe, T. Nagano, Monomeric (benzoato)manganese(II) complexes as manganese superoxide dismutase mimics, Inorg. Chem. 32 (1993) 1879-1880. https://doi.org/10.1021/ic00062a001.

[21] A. Deroche, I. Morgenstern-Badarau, M. Cesario, J. Guilhem, B. Keita, L. Nadjo, C. Houée-Levin, A Seven-Coordinate Manganese(II) Complex Formed with a Single Tripodal Heptadentate Ligand as a New Superoxide Scavenger, J. Am. Chem. Soc. 118 (1996) 4567-4573. https://doi.org/10.1021/ja9525081.

[22] K. Yamato, I. Miyahara, A. Ichimura, K. Hirotsu, Y. Kojima, H. Sakurai, D. Shiomi, K. Sato, T. Takui, Superoxide Dismutase Mimetic Complex of Mn(II) / N,N-Bis(2pyridylmethyl)-(S)-Histidine, Chem. Lett. 28 (1999) 295-296. https://doi.org/10.1246/cl.1999.295.

[23] C. Policar, S. Durot, F. Lambert, M. Cesario, F. Ramiandrasoa, I. Morgenstern- Badarau, New MnII Complexes with an N/O Coordination Sphere from Tripodal N-Centered Ligands - Characterization from Solid State to Solution and Reaction with Superoxide in Non-Aqueous and Aqueous Media, European Journal of Inorganic Chemistry. 2001 (2001) 1807-1818. https://doi.org/10.1002/10990682(200107)2001:7<1807::AID-EJIC1807>3.0.CO;2-Y.

[24] E.A. Lewis, H.H. Khodr, R.C. Hider, J.R.L. Smith, P.H. Walton, A manganese superoxide dismutase mimic based on cis,cis-1,3,5-triaminocyclohexane, Dalton Trans. (2004) 187-188. https://doi.org/10.1039/B314955B.

[25] Z.-R. Liao, X.-F. Zheng, B.-S. Luo, L.-R. Shen, D.-F. Li, H.-L. Liu, W. Zhao, Synthesis, characterization and SOD-like activities of manganese-containing complexes with $\mathrm{N}, \mathrm{N}, \mathrm{N}^{\prime}, \mathrm{N}^{\prime}$-tetrakis(2'-benzimidazolyl methyl)-1,2-ethanediamine (EDTB), Polyhedron. 20 (2001) 2813-2821. https://doi.org/10.1016/S02775387(01)00891-9. 
[26] S. Groni, G. Blain, R. Guillot, C. Policar, E. Anxolabéhère-Mallart, Reactivity of MnII with Superoxide. Evidence for a [MnIIIOO]+ Unit by Low-Temperature Spectroscopies, Inorg. Chem. 46 (2007) 1951-1953. https://doi.org/10.1021/ic062063+.

[27] F. Cisnetti, G. Pelosi, C. Policar, Synthesis and superoxide dismutase-like activity of new manganese(III) complexes based on tridentate N2O ligands derived from histamine, Inorganica Chimica Acta. 360 (2007) 557-562. https://doi.org/10.1016/j.ica.2006.07.112.

[28] J.W. Beyer, I. Fridovich, Characterization of a superoxide dismutase mimic prepared from desferrioxamine and MnO2., Arch Biochem Biophys. 271 (1989) 149-156. https://doi.org/10.1016/0003-9861(89)90265-8.

[29] K.M. Faulkner, R.D. Stevens, I. Fridovich, Characterization of Mn(III) Complexes of Linear and Cyclic Desferrioxamines as Mimics of Superoxide Dismutase Activity, Archives of Biochemistry and Biophysics. 310 (1994) 341-346. https://doi.org/10.1006/abbi.1994.1176.

[30] J. Lati, D. Meyerstein, Oxidation of first-row bivalent transition-metal complexes containing ethylenediaminetetra-acetate and nitrilotriacetate ligands by free radicals: a pulse-radiolysis study, J. Chem. Soc., Dalton Trans. (1978) 1105-1118. https://doi.org/10.1039/DT9780001105.

[31] J. Stein, J.P. Fackler, G.J. McClune, J.A. Fee, L.T. Chan, Superoxide and manganese(III). Reactions of manganese-EDTA and manganese-CyDTA complexes with molecular oxygen. X-ray structure of potassium manganese-EDTA.2 water, Inorg. Chem. 18 (1979) 3511-3519. https://doi.org/10.1021/ic50202a044.

[32] W.H. Koppenol, F. Levine, T.L. Hatmaker, J. Epp, J.D. Rush, Catalysis of superoxide dismutation by manganese aminopolycarboxylate complexes, Archives of Biochemistry and Biophysics. 251 (1986) 594-599. https://doi.org/10.1016/00039861(86)90368-1.

[33] F.S. Archibald, I. Fridovich, The scavenging of superoxide radical by manganous complexes: In vitro, Archives of Biochemistry and Biophysics. 214 (1982) 452-463. https://doi.org/10.1016/0003-9861(82)90049-2.

[34] M.A. Bailey, M.J. Ingram, D.P. Naughton, A novel anti-oxidant and anti-cancer strategy: a peptoid anti-inflammatory drug conjugate with SOD mimic activity, Biochemical and Biophysical Research Communications. 317 (2004) 1155-1158. https://doi.org/10.1016/j.bbrc.2004.03.162.

[35] A.E.O. Fisher, D.P. Naughton, Metal ion chelating peptides with superoxide dismutase activity, Biomedicine \& Pharmacotherapy. 59 (2005) 158-162. https://doi.org/10.1016/j.biopha.2005.03.008.

[36] T. Piacham, C. Isarankura-Na-Ayudhya, C. Nantasenamat, S. Yainoy, L. Ye, L. Bülow, V. Prachayasittikul, Metalloantibiotic Mn(II)-bacitracin complex mimicking manganese superoxide dismutase, Biochemical and Biophysical Research Communications. 341 (2006) 925-930. https://doi.org/10.1016/j.bbrc.2006.01.045.

[37] J.S. Valentine, A.E. Quinn, Reaction of superoxide with the manganese(III) tetraphenylporphine cation, Inorg. Chem. 15 (1976) 1997-1999. https://doi.org/10.1021/ic50162a058.

[38] K.M. Faulkner, S.I. Liochev, I. Fridovich, Stable Mn(III) porphyrins mimic superoxide dismutase in vitro and substitute for it in vivo., J. Biol. Chem. 269 (1994) 2347123476.

[39] I. Batinić-Haberle, S.I. Liochev, I. Spasojević, I. Fridovich, A Potent Superoxide Dismutase Mimic: Manganese $\beta$-Octabromo-meso-tetrakis-(N-methylpyridinium- 4-yl) Porphyrin, Archives of Biochemistry and Biophysics. 343 (1997) 225-233. 
https://doi.org/10.1006/abbi.1997.0157.

[40] I. Batinic-Haberle, L. Benov, I. Spasojevic, I. Fridovich, The Ortho Effect Makes Manganese(III) Meso -Tetrakis( $N$-Methylpyridinium-2-yl)Porphyrin a Powerful and Potentially Useful Superoxide Dismutase Mimic, Journal of Biological Chemistry. 273 (1998) 24521-24528. https://doi.org/10.1074/jbc.273.38.24521.

[41] P.J.F. Gauuan, M.P. Trova, L. Gregor-Boros, S.B. Bocckino, J.D. Crapo, B.J. Day, Superoxide dismutase mimetics: synthesis and structure-activity relationship study of MnTBAP analogues, Bioorganic \& Medicinal Chemistry. 10 (2002) 3013-3021. https://doi.org/10.1016/S0968-0896(02)00153-0.

[42] I. Batinić-Haberle, I. Spasojević, R.D. Stevens, B. Bondurant, A. Okado-Matsumoto, I. Fridovich, Ž. Vujašković, M.W. Dewhirst, New PEG-ylated Mn( III ) porphyrins approaching catalytic activity of SOD enzyme, Dalton Trans. (2006) 617-624. https://doi.org/10.1039/B513761F.

[43] F. Matemadombo, M. Durmus, V. Escriou, S. Griveau, D. Scherman, F. Bedioui, T. Nyokong, Evaluation of the Performance of Manganese Phthalocyanines as Superoxide Dismutase Mimics, CAC. 5 (2009) 330-338. https://doi.org/10.2174/157341109789077731.

[44] J.T. Brewster, G.D. Thiabaud, P. Harvey, H. Zafar, J.F. Reuther, S. Dell'Acqua, R.M. Johnson, H.D. Root, P. Metola, A. Jasanoff, L. Casella, J.L. Sessler, Metallotexaphyrins as MRI-Active Catalytic Antioxidants for Neurodegenerative Disease: A Study on Alzheimer's Disease, Chem. 6 (2020) 703-724. https://doi.org/10.1016/j.chempr.2019.12.016.

[45] J.F. Arambula, C. Preihs, D. Borthwick, D. Magda, J.L. Sessler, Texaphyrins: Tumor Localizing Redox Active Expanded Porphyrins, Anticancer Agents Med Chem. 11 (2011) 222-232.

[46] L.M.F. Gomes, A. Mahammed, K.E. Prosser, J.R. Smith, M.A. Silverman, C.J. Walsby, Z. Gross, T. Storr, A catalytic antioxidant for limiting amyloid-beta peptide aggregation and reactive oxygen species generation, Chem. Sci. (2018). https://doi.org/10.1039/C8SC04660C.

[47] Z. Okun, L. Kupershmidt, M.B.H.Y. and Z. Gross, Cellular Uptake and Organ Accumulation of Amphipolar Metallocorroles with Cytoprotective and Cytotoxic Properties, Anti-Cancer Agents in Medicinal Chemistry. 11 (2011) 380-384. http://www.eurekaselect.com/74149/article (accessed March 26, 2020).

[48] A. Haber, Z. Gross, Catalytic antioxidant therapy by metallodrugs: lessons from metallocorroles, Chem. Commun. 51 (2015) 5812-5827. https://doi.org/10.1039/C4CC08715A.

[49] I. Spasojević, I. Batinić-Haberle, R.D. Stevens, P. Hambright, A.N. Thorpe, J. Grodkowski, P. Neta, I. Fridovich, Manganese(III) Biliverdin IX Dimethyl Ester: A Powerful Catalytic Scavenger of Superoxide Employing the Mn(III)/Mn(IV) Redox Couple, Inorganic Chemistry. 40 (2001) 726-739. https://doi.org/10.1021/ic0004986.

[50] M.N. Patel, Metalloporphyrins improve the survival of Sod2-deficient neurons, Aging Cell. 2 (2003) 219-222. https://doi.org/10.1046/j.1474-9728.2003.00055.x.

[51] W. Munroe, C. Kingsley, A. Durazo, E. Butler Gralla, J.A. Imlay, C. Srinivasan, J. Selverstone Valentine, Only one of a wide assortment of manganese-containing SOD mimicking compounds rescues the slow aerobic growth phenotypes of both Escherichia coli and Saccharomyces cerevisiae strains lacking superoxide dismutase enzymes, Journal of Inorganic Biochemistry. 101 (2007) 1875-1882. https://doi.org/10.1016/j.jinorgbio.2007.07.008.

[52] J.M. Pollard, J.S. Reboucas, A. Durazo, I. Kos, F. Fike, M. Panni, E.B. Gralla, J.S. Valentine, I. Batinic-Haberle, R.A. Gatti, Radioprotective effects of manganese- 
containing superoxide dismutase mimics on ataxia-telangiectasia cells, Free Radical Biology and Medicine. 47 (2009) 250-260.

https://doi.org/10.1016/j.freeradbiomed.2009.04.018.

[53] J. Alexandre, C. Nicco, C. Chéreau, A. Laurent, B. Weill, F. Goldwasser, F. Batteux, Improvement of the Therapeutic Index of Anticancer Drugs by the Superoxide Dismutase Mimic Mangafodipir, J Natl Cancer Inst. 98 (2006) 236-244. https://doi.org/10.1093/jnci/djj049.

[54] M.R. Filipović, A.C.W. Koh, S. Arbault, V. Niketić, A. Debus, U. Schleicher, C. Bogdan, M. Guille, F. Lemaître, C. Amatore, I. Ivanović- Burmazović, Striking Inflammation from Both Sides: Manganese(II) Pentaazamacrocyclic SOD Mimics Act Also as Nitric Oxide Dismutases: A Single-Cell Study, Angewandte Chemie International Edition. 49 (n.d.) 4228-4232. https://doi.org/10.1002/anie.200905936.

[55] A.-S. Bernard, C. Giroud, H.Y.V. Ching, A. Meunier, V. Ambike, C. Amatore, M.G. Collignon, F. Lemaître, C. Policar, Evaluation of the anti-oxidant properties of a SODmimic Mn-complex in activated macrophages, Dalton Trans. 41 (2012) 6399-6403. https://doi.org/10.1039/C2DT12479C.

[56] B. Gauter-Fleckenstein, K. Fleckenstein, K. Owzar, C. Jian, I. Batinic-Haberle, Z. Vujaskovic, Comparison of two Mn porphyrin-based mimics of superoxide dismutase (SOD) in pulmonary radioprotection, Free Radic Biol Med. 44 (2008) 982-989. https://doi.org/10.1016/j.freeradbiomed.2007.10.058.

[57] B. Gauter-Fleckenstein, K. Fleckenstein, K. Owzar, C. Jiang, J.S. Rebouças, I. BatinicHaberle, Z. Vujaskovic, Early and late administration of MnTE-2-PyP5+ in mitigation and treatment of radiation-induced lung damage, Free Radical Biology and Medicine. 48 (2010) 1034-1043. https://doi.org/10.1016/j.freeradbiomed.2010.01.020.

[58] S.R. Doctrow, A. Lopez, A.M. Schock, N.E. Duncan, M.M. Jourdan, E.B. Olasz, J.E. Moulder, B.L. Fish, M. Mäder, J. Lazar, Z. Lazarova, A Synthetic Superoxide Dismutase/Catalase Mimetic EUK-207 Mitigates Radiation Dermatitis and Promotes Wound Healing in Irradiated Rat Skin, Journal of Investigative Dermatology. 133 (2013) 1088-1096. https://doi.org/10.1038/jid.2012.410.

[59] S.R. Doctrow, K. Huffman, C.B. Marcus, G. Tocco, E. Malfroy, C.A. Adinolfi, H. Kruk, K. Baker, N. Lazarowych, J. Mascarenhas, B. Malfroy, Salen-Manganese Complexes as Catalytic Scavengers of Hydrogen Peroxide and Cytoprotective Agents: Structure-Activity Relationship Studies, Journal of Medicinal Chemistry. 45 (2002) 4549-4558. https://doi.org/10.1021/jm020207y.

[60] H. Sheng, J.J. Enghild, R. Bowler, M. Patel, I. Batinić-Haberle, C.L. Calvi, B.J. Day, R.D. Pearlstein, J.D. Crapo, D.S. Warner, Effects of metalloporphyrin catalytic antioxidants in experimental brain ischemia, Free Radical Biology and Medicine. 33 (2002) 947-961. https://doi.org/10.1016/S0891-5849(02)00979-6.

[61] E. Masini, S. Cuzzocrea, E. Mazzon, C. Marzocca, P.F. Mannaioni, D. Salvemini, Protective effects of M40403, a selective superoxide dismutase mimetic, in myocardial ischaemia and reperfusion injury in vivo, British Journal of Pharmacology. 136 (2002) 905-917. https://doi.org/10.1038/sj.bjp.0704774.

[62] Y. Rong, S.R. Doctrow, G. Tocco, M. Baudry, EUK-134, a synthetic superoxide dismutase and catalase mimetic, prevents oxidative stress and attenuates kainateinduced neuropathology, PNAS. 96 (1999) 9897-9902. https://doi.org/10.1073/pnas.96.17.9897.

[63] M.C. McDonald, R. d'Emmanuele di Villa Bianca, N.S. Wayman, A. Pinto, M.A. Sharpe, S. Cuzzocrea, P.K. Chatterjee, C. Thiemermann, A superoxide dismutase mimetic with catalase activity (EUK-8) reduces the organ injury in endotoxic shock, European Journal of Pharmacology. 466 (2003) 181-189. 
https://doi.org/10.1016/S0014-2999(03)01538-3.

[64] E. Masini, D. Bani, A. Vannacci, S. Pierpaoli, P.F. Mannaioni, S.A.A. Comhair, W. $\mathrm{Xu}$, C. Muscoli, S.C. Erzurum, D. Salvemini, Reduction of antigen-induced respiratory abnormalities and airway inflammation in sensitized guinea pigs by a superoxide dismutase mimetic, Free Radical Biology and Medicine. 39 (2005) 520-531. https://doi.org/10.1016/j.freeradbiomed.2005.04.006.

[65] M.-A. Guillaumot, O. Cerles, H.C. Bertrand, E. Benoit, C. Nicco, S. Chouzenoux, A. Schmitt, F. Batteux, C. Policar, R. Coriat, Oxaliplatin-induced neuropathy: the preventive effect of a new super-oxide dismutase modulator, Oncotarget. 10 (2019) 6418-6431. https://doi.org/10.18632/oncotarget.27248.

[66] I. Batinic-Haberle, M.E. Tome, Thiol regulation by Mn porphyrins, commonly known as SOD mimics, Redox Biology. 25 (2019) 101139.

https://doi.org/10.1016/j.redox.2019.101139.

[67] A. Tovmasyan, C.G.C. Maia, T. Weitner, S. Carballal, R.S. Sampaio, D. Lieb, R. Ghazaryan, I. Ivanovic-Burmazovic, G. Ferrer-Sueta, R. Radi, J.S. Reboucas, I. Spasojevic, L. Benov, I. Batinic-Haberle, A comprehensive evaluation of catalase-like activity of different classes of redox-active therapeutics, Free Radical Biology and Medicine. 86 (2015) 308-321. https://doi.org/10.1016/j.freeradbiomed.2015.05.018.

[68] A. Tovmasyan, J.C. Bueno-Janice, M.C. Jaramillo, R.S. Sampaio, J.S. Reboucas, N. Kyui, L. Benov, B. Deng, T.-T. Huang, M.E. Tome, I. Spasojevic, I. Batinic-Haberle, Radiation-Mediated Tumor Growth Inhibition Is Significantly Enhanced with RedoxActive Compounds That Cycle with Ascorbate, Antioxidants \& Redox Signaling. 29 (2018) 1196-1214. https://doi.org/10.1089/ars.2017.7218.

[69] S. Signorella, C. Palopoli, G. Ledesma, Rationally designed mimics of antioxidant manganoenzymes: Role of structural features in the quest for catalysts with catalase and superoxide dismutase activity, Coordination Chemistry Reviews. 365 (2018) 75102. https://doi.org/10.1016/j.ccr.2018.03.005.

[70] I. Batinic-Haberle, A. Tovmasyan, I. Spasojevic, Mn Porphyrin-Based Redox-Active Drugs: Differential Effects as Cancer Therapeutics and Protectors of Normal Tissue Against Oxidative Injury, Antioxidants \& Redox Signaling. 29 (2018) 1691-1724. https://doi.org/10.1089/ars.2017.7453.

[71] Z. Rajic, A. Tovmasyan, I. Spasojevic, H. Sheng, M. Lu, A.M. Li, E.B. Gralla, D.S. Warner, L. Benov, I. Batinic-Haberle, A new SOD mimic, Mn(III) ortho Nbutoxyethylpyridylporphyrin, combines superb potency and lipophilicity with low toxicity, Free Radical Biology and Medicine. 52 (2012) 1828-1834. https://doi.org/10.1016/j.freeradbiomed.2012.02.006.

[72] J.S. Rebouças, I. Spasojević, I. Batinić-Haberle, Pure manganese(III) 5,10,15,20tetrakis(4-benzoic acid)porphyrin (MnTBAP) is not a superoxide dismutase mimic in aqueous systems: a case of structure-activity relationship as a watchdog mechanism in experimental therapeutics and biology, J Biol Inorg Chem. 13 (2008) 289-302. https://doi.org/10.1007/s00775-007-0324-9.

[73] I. Batinić-Haberle, I. Spasojević, P. Hambright, L. Benov, A.L. Crumbliss, I. Fridovich, Relationship among Redox Potentials, Proton Dissociation Constants of Pyrrolic Nitrogens, and in Vivo and in Vitro Superoxide Dismutating Activities of Manganese(III) and Iron(III) Water-Soluble Porphyrins, Inorganic Chemistry. 38 (1999) 4011-4022. https://doi.org/10.1021/ic990118k.

[74] I. Batinić-Haberle, I. Spasojević, R. D. Stevens, P. Hambright, I. Fridovich, Manganese( iii ) meso -tetrakis( ortho - N -alkylpyridyl)porphyrins. Synthesis, characterization, and catalysis of $\mathrm{O} 2^{\circ}$ - dismutation, Journal of the Chemical Society, Dalton Transactions. 0 (2002) 2689-2696. https://doi.org/10.1039/B201057G. 
[75] F. Cisnetti, A.-S. Lefèvre, R. Guillot, F. Lambert, G. Blain, E. Anxolabéhère-Mallart, C. Policar, A New Pentadentate Ligand Forms Both a Di- and a Mononuclear MnII Complex: Electrochemical, Spectroscopic and Superoxide Dismutase Activity Studies, European Journal of Inorganic Chemistry. 2007 (2007) 4472-4480. https://doi.org/10.1002/ejic.200601236.

[76] A. Tighe, O. Staples, S. Taylor, Mps1 kinase activity restrains anaphase during an unperturbed mitosis and targets Mad2 to kinetochores, J Cell Biol. 181 (2008) 893901. https://doi.org/10.1083/jcb.200712028.

[77] I. Amblard, M. Thauvin, C. Rampon, I. Queguiner, V.V. Pak, V. Belousov, A. Prochiantz, M. Volovitch, A. Joliot, S. Vriz, H 2 O 2 and Engrailed 2 paracrine activity synergize to shape the zebrafish optic tectum, Communications Biology. 3 (2020) 1-9. https://doi.org/10.1038/s42003-020-01268-7.

[78] C. Lenoir, C. Sapin, A.H. Broquet, A.M. Jouniaux, S. Bardin, I. Gasnereau, G. Thomas, P. Seksik, G. Trugnan, J. Masliah, M. Bachelet, MD-2 controls bacterial lipopolysaccharide hyporesponsiveness in human intestinal epithelial cells., Life Sci. 82 (2008) 519-528. https://doi.org/10.1016/j.lfs.2007.12.007.

[79] V. Grondin, P. Seksik, S. Dumont, G. Thomas, G. Trugnan, J.F. Fléjou, J. Masliah, D. Wendum, M. Bachelet, Regulation of colon cancer cell proliferation and migration by MD-2 activity, Innate Immun. 17 (2011) 414-422. https://doi.org/10.1177/1753425910375583.

[80] S. Goldstein, G. Merenyi, A. Russo, A. Samuni, The Role of Oxoammonium Cation in the SOD-Mimic Activity of Cyclic Nitroxides, J. Am. Chem. Soc. 125 (2003) 789-795. https://doi.org/10.1021/ja028190w.

[81] Y.N. Antonenko, A.V. Avetisyan, L.E. Bakeeva, B.V. Chernyak, V.A. Chertkov, L.V. Domnina, O.Yu. Ivanova, D.S. Izyumov, L.S. Khailova, S.S. Klishin, G.A.

Korshunova, K.G. Lyamzaev, M.S. Muntyan, O.K. Nepryakhina, A.A. Pashkovskaya, O.Yu. Pletjushkina, A.V. Pustovidko, V.A. Roginsky, T.I. Rokitskaya, E.K. Ruuge, V.B. Saprunova, I.I. Severina, R.A. Simonyan, I.V. Skulachev, M.V. Skulachev, N.V. Sumbatyan, I.V. Sviryaeva, V.N. Tashlitsky, J.M. Vassiliev, M.Yu. Vyssokikh, L.S. Yaguzhinsky, A.A. Zamyatnin, V.P. Skulachev, Mitochondria-targeted plastoquinone derivatives as tools to interrupt execution of the aging program. 1. Cationic plastoquinone derivatives: Synthesis and in vitro studies, Biochemistry Moscow. 73 (2008) 1273-1287. https://doi.org/10.1134/S0006297908120018.

[82] I. Spasojević, Y. Chen, T.J. Noel, Y. Yu, M.P. Cole, L. Zhang, Y. Zhao, D.K. St. Clair, I. Batinić-Haberle, Mn porphyrin-based superoxide dismutase (SOD) mimic, MnIIITE2-PyP5+, targets mouse heart mitochondria, Free Radical Biology and Medicine. 42 (2007) 1193-1200. https://doi.org/10.1016/j.freeradbiomed.2007.01.019.

[83] R.A.J. Smith, C.M. Porteous, A.M. Gane, M.P. Murphy, Delivery of bioactive molecules to mitochondria in vivo, PNAS. 100 (2003) 5407-5412. https://doi.org/10.1073/pnas.0931245100.

[84] J. Trnka, F.H. Blaikie, A. Logan, R.A.J. Smith, M.P. Murphy, Antioxidant properties of MitoTEMPOL and its hydroxylamine, Free Radical Research. 43 (2009) 4-12. https://doi.org/10.1080/10715760802582183.

[85] H.Y.V. Ching, I. Kenkel, N. Delsuc, E. Mathieu, I. Ivanović-Burmazović, C. Policar, Bioinspired superoxide-dismutase mimics: The effects of functionalization with cationic polyarginine peptides, Journal of Inorganic Biochemistry. 160 (2016) 172179. https://doi.org/10.1016/j.jinorgbio.2016.01.025.

[86] F.C. Friedel, D. Lieb, I. Ivanović-Burmazović, Comparative studies on manganesebased SOD mimetics, including the phosphate effect, by using global spectral analysis, Journal of Inorganic Biochemistry. 109 (2012) 26-32. 
https://doi.org/10.1016/j.jinorgbio.2011.12.008.

[87] S. Melov, S.R. Doctrow, J.A. Schneider, J. Haberson, M. Patel, P.E. Coskun, K. Huffman, D.C. Wallace, B. Malfroy, Lifespan Extension and Rescue of Spongiform Encephalopathy in Superoxide Dismutase 2 Nullizygous Mice Treated with Superoxide Dismutase-Catalase Mimetics, J. Neurosci. 21 (2001) 8348-8353. https://doi.org/10.1523/JNEUROSCI.21-21-08348.2001.

[88] K. Barnese, E.B. Gralla, D.E. Cabelli, J. Selverstone Valentine, Manganous Phosphate Acts as a Superoxide Dismutase, Journal of the American Chemical Society. 130 (2008) 4604-4606. https://doi.org/10.1021/ja710162n.

[89] S. Durot, C. Policar, F. Cisnetti, F. Lambert, J.-P. Renault, G. Pelosi, G. Blain, H. Korri-Youssoufi, J.-P. Mahy, Series of Mn Complexes Based onN-Centered Ligands and Superoxide - Reactivity in an Anhydrous Medium and SOD-Like Activity in an Aqueous Medium Correlated to MnII/MnIII Redox Potentials, European Journal of Inorganic Chemistry. 2005 (2005) 3513-3523. https://doi.org/10.1002/ejic.200400835.

[90] S. Goldstein, I. Fridovich, G. Czapski, Kinetic properties of Cu,Zn-superoxide dismutase as a function of metal content-Order restored, Free Radical Biology and Medicine. 41 (2006) 937-941. https://doi.org/10.1016/j.freeradbiomed.2006.05.026.

[91] C.K. Vance, A.-F. Miller, A Simple Proposal That Can Explain the Inactivity of MetalSubstituted Superoxide Dismutases, J. Am. Chem. Soc. 120 (1998) 461-467. https://doi.org/10.1021/ja972060j.

[92] L.M. Ellerby, D.E. Cabelli, J.A. Graden, J.S. Valentine, Copper-Zinc Superoxide Dismutase: Why Not pH-Dependent?, J. Am. Chem. Soc. 118 (1996) 6556-6561. https://doi.org/10.1021/ja953845x.

[93] I.A. Abreu, D.E. Cabelli, Superoxide dismutases - a review of the metal-associated mechanistic variations, Biochimica et Biophysica Acta (BBA) - Proteins and Proteomics. 1804 (2010) 263-274. https://doi.org/10.1016/j.bbapap.2009.11.005.

[94] J.S. Rebouças, I. Spasojević, I. Batinić-Haberle, Pure manganese(III) 5,10,15,20tetrakis(4-benzoic acid)porphyrin (MnTBAP) is not a superoxide dismutase mimic in aqueous systems: a case of structure-activity relationship as a watchdog mechanism in experimental therapeutics and biology, J Biol Inorg Chem. 13 (2008) 289-302. https://doi.org/10.1007/s00775-007-0324-9.

[95] I. Batinić-Haberle, S. Cuzzocrea, J.S. Rebouças, G. Ferrer-Sueta, E. Mazzon, R. Di Paola, R. Radi, I. Spasojević, L. Benov, D. Salvemini, Pure MnTBAP selectively scavenges peroxynitrite over superoxide: Comparison of pure and commercial MnTBAP samples to MnTE-2-PyP in two models of oxidative stress injury, an SODspecific Escherichia coli model and carrageenan-induced pleurisy, Free Radical Biology and Medicine. 46 (2009) 192-201. https://doi.org/10.1016/j.freeradbiomed.2008.09.042.

[96] S. Da Rocha, J. Bigot, F. Onodi, J. Cosette, G. Corre, J. Poupiot, D. Fenard, B. Gjata, A. Galy, T.M.A. Neildez-Nguyen, Temporary Reduction of Membrane CD4 with the Antioxidant MnTBAP Is Sufficient to Prevent Immune Responses Induced by Gene Transfer, Molecular Therapy - Methods \& Clinical Development. 14 (2019) 285-299. https://doi.org/10.1016/j.omtm.2019.06.011.

[97] C. Amatore, S. Arbault, M. Guille, F. Lemaître, Electrochemical Monitoring of Single Cell Secretion: Vesicular Exocytosis and Oxidative Stress, Chem. Rev. 108 (2008) 2585-2621. https://doi.org/10.1021/cr068062g.

[98] C.A. Harris, K.S. Derbin, B. Hunte-McDonough, M.R. Krauss, K.T. Chen, D.M. Smith, L.B. Epstein, Manganese superoxide dismutase is induced by IFN-gamma in multiple cell types. Synergistic induction by IFN-gamma and tumor necrosis factor or IL-1., The Journal of Immunology. 147 (1991) 149-154. 
[99] V.V. Belousov, A.F. Fradkov, K.A. Lukyanov, D.B. Staroverov, K.S. Shakhbazov, A.V. Terskikh, S. Lukyanov, Genetically encoded fluorescent indicator for intracellular hydrogen peroxide, Nat Methods. 3 (2006) 281-286. https://doi.org/10.1038/nmeth866.

[100] N.M. Mishina, K.N. Markvicheva, D.S. Bilan, M.E. Matlashov, M.V. Shirmanova, D. Liebl, C. Schultz, S. Lukyanov, V.V. Belousov, Chapter Three - Visualization of Intracellular Hydrogen Peroxide with HyPer, a Genetically Encoded Fluorescent Probe, in: E. Cadenas, L. Packer (Eds.), Methods in Enzymology, Academic Press, 2013: pp. 45-59. https://doi.org/10.1016/B978-0-12-405883-5.00003-X.

[101] E. Cadenas, K.J.A. Davies, Guest Editors: Enrique Cadenas and Kelvin J. A. Davies, Oxidative Stress. (n.d.) 9.

[102] C.M. Weekley, I. Kenkel, R. Lippert, S. Wei, D. Lieb, T. Cranwell, J.L. Wedding, A.S. Zillmann, R. Rohr, M.R. Filipovic, I. Ivanović-Burmazović, H.H. Harris, Cellular Fates of Manganese(II) Pentaazamacrocyclic Superoxide Dismutase (SOD) Mimetics:

Fluorescently Labeled MnSOD Mimetics, X-ray Absorption Spectroscopy, and X-ray Fluorescence Microscopy Studies, Inorg. Chem. 56 (2017) 6076-6093. https://doi.org/10.1021/acs.inorgchem.6b03073.

[103] E. Mathieu, A.-S. Bernard, E. Quévrain, M. Zoumpoulaki, S. Iriart, C. Lung-Soong, B. Lai, K. Medjoubi, L. Henry, S. Nagarajan, F. Poyer, A. Scheitler, I. IvanovićBurmazović, S. Marco, A. Somogyi, P. Seksik, N. Delsuc, C. Policar, Intracellular location matters: rationalization of the anti-inflammatory activity of a manganese(II) superoxide dismutase mimic complex, Chem. Commun. 56 (2020) 7885-7888. https://doi.org/10.1039/D0CC03398G.

[104] C.C. Winterbourn, Biological Production, Detection, and Fate of Hydrogen Peroxide, Antioxidants \& Redox Signaling. 29 (2018) 541-551. https://doi.org/10.1089/ars.2017.7425.

[105] J.F. Valentine, H.S. Nick, Acute-phase induction of manganese superoxide dismutase in intestinal epithelial cell lines, Gastroenterology. 103 (1992) 905-912. https://doi.org/10.1016/0016-5085(92)90024-S.

[106] M.C. Denis, A. Furtos, S. Dudonné, A. Montoudis, C. Garofalo, Y. Desjardins, E. Delvin, E. Levy, Apple Peel Polyphenols and Their Beneficial Actions on Oxidative Stress and Inflammation, PLOS ONE. 8 (2013) e53725. https://doi.org/10.1371/journal.pone.0053725.

[107] E. Mathieu, A.-S. Bernard, H.Y.V. Ching, A. Somogyi, K. Medjoubi, J.R. Fores, H.C. Bertrand, A. Vincent, S. Trépout, J.-L. Guerquin-Kern, A. Scheitler, I. IvanovićBurmazović, P. Seksik, N. Delsuc, C. Policar, Anti-inflammatory activity of superoxide dismutase mimics functionalized with cell-penetrating peptides, Dalton Trans. 49 (2020) 2323-2330. https://doi.org/10.1039/C9DT04619D.

[108] Q.-Y. Li, C. Pedersen, B.J. Day, M. Patel, Dependence of excitotoxic neurodegeneration on mitochondrial aconitase inactivation, Journal of Neurochemistry. 78 (2001) 746-755. https://doi.org/10.1046/j.1471-4159.2001.00457.x.

[109] Y. Zhao, D.W. Carroll, Y. You, L. Chaiswing, R. Wen, I. Batinic-Haberle, S. Bondada, Y. Liang, D.K. St. Clair, A novel redox regulator, MnTnBuOE-2-PyP5+, enhances normal hematopoietic stem/progenitor cell function, Redox Biology. 12 (2017) 129138. https://doi.org/10.1016/j.redox.2017.02.005. 